\title{
Flavonoids in Cancer and Apoptosis
}

\author{
Mariam Abotaleb $^{1}$, Samson Mathews Samuel ${ }^{1}\left(\mathbb{D}\right.$, Elizabeth Varghese ${ }^{1}$, Sharon Varghese ${ }^{1}(\mathbb{D}$, \\ Peter Kubatka ${ }^{2}$, Alena Liskova ${ }^{3}$ and Dietrich Büsselberg ${ }^{1, *}$ \\ 1 Department of Physiology and Biophysics, Weill Cornell Medicine-Qatar, Education City, Qatar Foundation, \\ Doha, P.O. Box 24144, Qatar; mariam.abotaleb@aucegypt.edu (M.A.); \\ sms2016@qatar-med.cornell.edu (S.M.S.); elv2007@qatar-med.cornell.edu (E.V.); \\ scv2002@qatar-med.cornell.edu (S.V.) \\ 2 Department of Medical Biology, Jessenius Faculty of Medicine, Comenius University in Bratislava, \\ 03601 Martin, Slovakia; kubatka@jfmed.uniba.sk \\ 3 Clinic of Obstetrics and Gynecology, Jessenius Faculty of Medicine, Comenius University in Bratislava, \\ 03601 Martin, Slovakia; alenka.liskova@gmail.com \\ * Correspondence: dib2015@qatar-med.cornell.edu; Tel.: +974-4492-8334; Fax: +974-4492-8333
}

Received: 22 November 2018; Accepted: 13 December 2018; Published: 28 December 2018

check for updates

\begin{abstract}
Cancer is the second leading cause of death globally. Although, there are many different approaches to cancer treatment, they are often painful due to adverse side effects and are sometimes ineffective due to increasing resistance to classical anti-cancer drugs or radiation therapy. Targeting delayed/inhibited apoptosis is a major approach in cancer treatment and a highly active area of research. Plant derived natural compounds are of major interest due to their high bioavailability, safety, minimal side effects and, most importantly, cost effectiveness. Flavonoids have gained importance as anti-cancer agents and have shown great potential as cytotoxic anti-cancer agents promoting apoptosis in cancer cells. In this review, a summary of flavonoids and their effectiveness in cancer treatment targeting apoptosis has been discussed.
\end{abstract}

Keywords: anti-cancer therapy; apoptosis; cancer; flavonoids; natural compounds; phytochemicals

\section{Introduction}

Cancer is a heterogeneous disease triggered by irreversible impairment of cellular homeostasis and function. Cancer progression is a result of uncontrolled cell growth and differentiation along with loss of apoptotic functions leading to a massive expansion in neoplastic cells population [1,2]. Internal causes of cancer may be attributed to lack of apoptotic function, genetic mutations, oxidative stress, and hypoxia, while external causes of cancer may be linked to excessive exposure to ultraviolet rays, radiation, pollution, smoking, and stress [3]. There are six hallmarks that contribute tumorigenesis and distinguish cancer cells from normal healthy ones (Figure 1) $[4,5]$. 


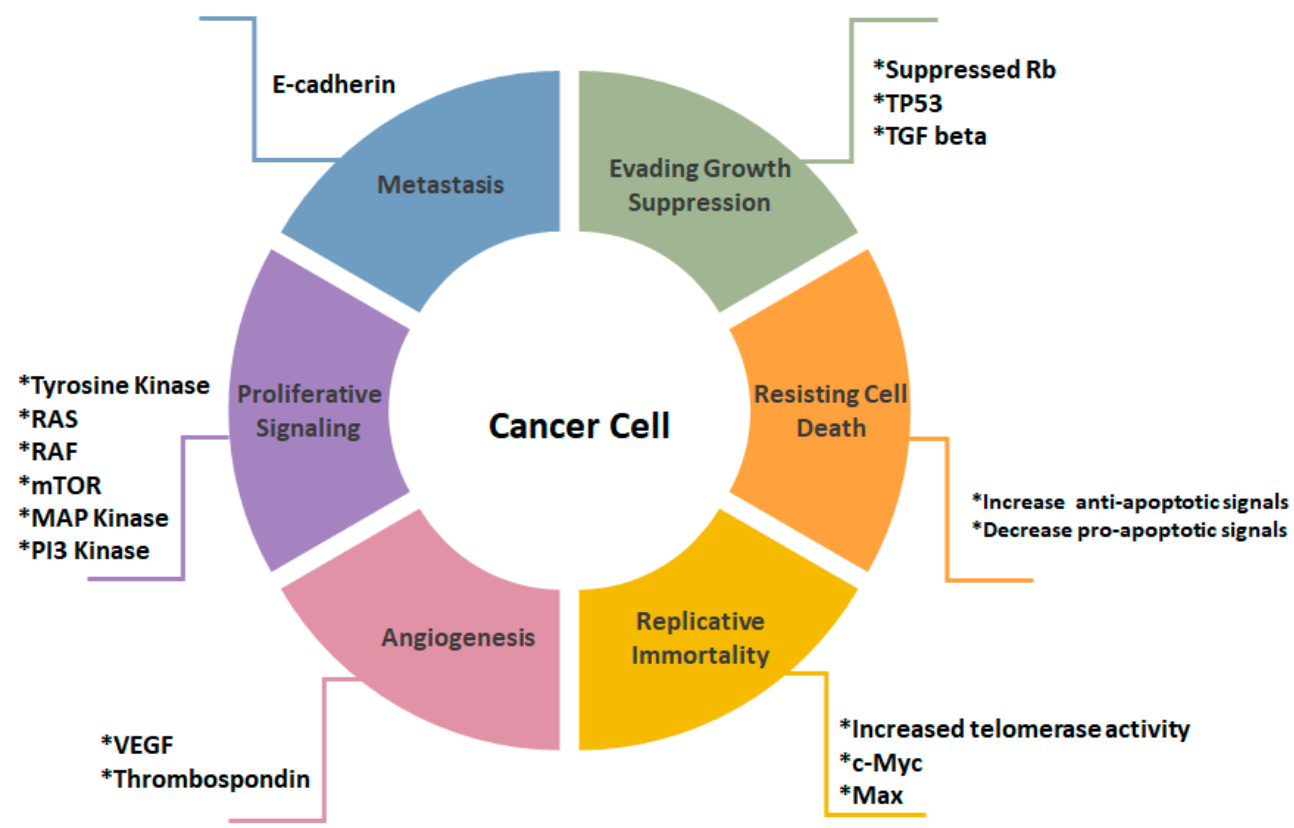

Figure 1. Illustration of cancer cell hallmarks. Evasion of growth suppression is mediated by inhibition of $\mathrm{Rb}, \mathrm{TP} 53$ and TGF beta. Resistance in cell death is signified by increase in anti-apoptotic and a decrease in pro-apoptotic factors. Replicative immortality is result of an increase in telomerase activity, c-Myc and Max. Angiogenesis is promoted due to the increase in VEGF and thrombospondin. The increased proliferative signaling is emphasized by increased tyrosine kinase activity, Ras, Raf, $\mathrm{m}$-TOR, MAP kinase and PI3-kinase. Metastasis formation is marked by the loss of E-cadherin [4].

\section{Apoptosis}

Apoptosis is a stringently organized process, regulated by a series of signal transduction cascades and cellular proteins [6]. Cancer and many other diseases such as AIDS, diabetes, and Parkinson's syndrome, occur as a result of imbalances and aberrant mechanisms in apoptotic pathways [7]. Thus, a profound understanding of apoptotic mechanisms and related pathways not only serves in comprehending the disease but also in disease treatment [8].

\subsection{Apoptotic Proteins}

Classification of apoptotic proteins depends primarily on their role in apoptosis (Figure 2B). Pro-apoptotic proteins are further classified depending on the protein family into (1) caspases and (2) Bcl2 family:

(1) Caspases, aspartate-specific cysteine proteases [1,6] possess a key role in apoptosis induction and are usually found as inactive heterodimers known as procaspases [6,9]. There are 14 known proteins belonging to caspases classified according to their structure and function (Figure 2A).

(2) Bcl-2 family (Figure 2B) regulates cells behavior through programmed cell death $[8,10]$. Localized to the outer membrane of the mitochondria, it mainly modulates the release of cytochrome c. $\mathrm{Bcl}-2$ family of proteins is structurally distinguished by the presence of a BH3 domain [10]. Bcl-2 family either induces apoptosis via multi domain Bax/Bak or inhibits anti-apoptotic proteins (IAPs) belonging to BH3 only family including Puma, Noxa, Bim, Bad, Smac/Diablo, Hrta/Omi, Arts. Puma and Noxa which are crucial in cytokines induced apoptosis are produced as a result of DNA damage and transcription of P53 [2,6,11]. Bad (which is induced by nutrition deprivation and growth signals) [7,12], Smac/Diablo, Hrta/Omi, and Arts are all produced as a result of MOMP [7]. Anti-apoptotic proteins (Figure 2B), members of the Bcl-2 family functioning as apoptosis inhibitors, are subclassified into multi BH domain containing Bcl-xL, Bcl-B, Bcl-W, Mcl-1, Bf1 Diva/Boo. Under unstressed cellular conditions these proteins are upregulated in order to bind, interact, and sequester the pro-apoptotic Bax and Bak, preserving the mitochondrial membrane integrity $[7,8]$. BIR domain of anti-apoptotic 
proteins include N-IAP, c-IAP 1, c-IAP 2, and x-IAP. Testis specific survivin and ubiquitin conjugating enzymes livin and bruce/appollon all function mainly through the inhibition of caspases $[7,8]$.

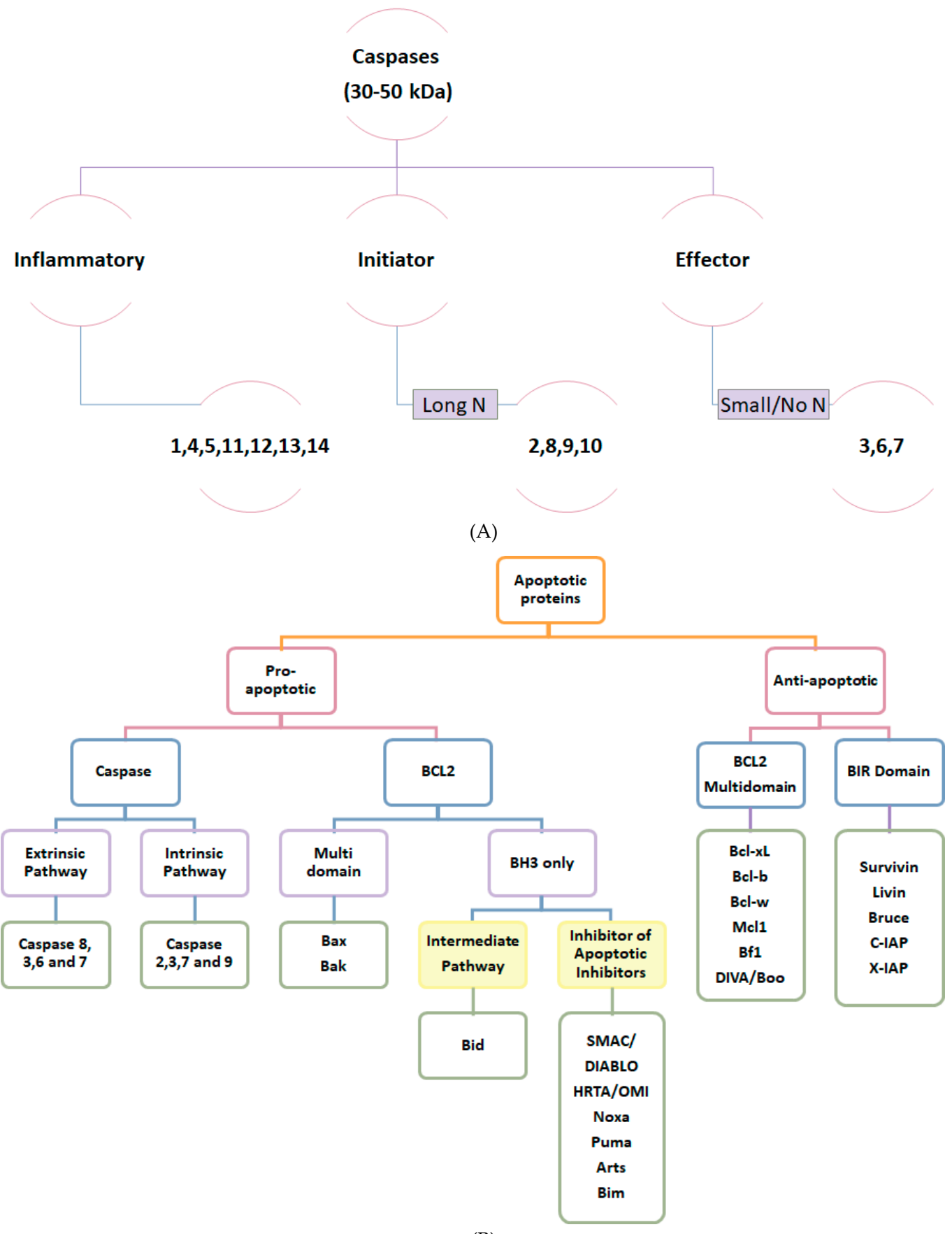

(B)

Figure 2. (A) Classification of caspases. Caspases are divided into three subtypes: inflammatory caspases $(1,4,5,11,12,13,14)$, initiator caspases in intrinsic and extrinsic apoptotic pathways with long $\mathrm{N}$ terminal $(2,8,9,10)$, and effector caspases known for their short/absent $\mathrm{N}$-terminal $(3,6,7)[6,8]$. (B) Classification of apoptotic proteins according to their function in apoptosis. Pro-apoptotic proteins are classified into Caspases and BCL-2 families. Caspases are further subdivided according to their role in apoptotic pathway. Bcl-2 proteins are classified as multidomain proteins (Bax and Bak) and $\mathrm{BH} 3$ only domain that either serve in intermediate pathway (Bid and inhibitors of apoptotic inhibitors such as SMAC/Diablo, HRTA/Omi, Noxa, Puma, Arts and Bim). Anti-apoptotic proteins are classified as BCL-2 multi-domain proteins (Bcl-xl, Bcl-b, Bcl-w, Mcl-1, Bf1 and DIVA/Boo) and BIR domain family (survivin, livin, bruce, c-IAP and x-IAP). 


\subsection{The Apoptotic Pathway}

Two major pathways contributing to apoptosis are shown in Figure 3 [13]. Firstly, the extrinsic/death receptor induced pathway and secondly, the intrinsic pathway in which mitochondrial stress is involved. In extrinsic pathway the activation of signal transduction cascade occurs via binding of death signals to trimeric death ligands such as Fas and TNF $[1,6]$. Once an extra cellular death signal is received, initiator procaspases-8 and -10 (bound to the inner membrane FADD/TRADD regions of death receptors) are activated which results in the formation of a DISC complex and thus the signal transduction cascade proceeds $[1,6,13]$. Subsequently, activated caspase- 3 functions in the activation of the mitochondrial amplification loop through the Bid protein containing BH3 only domain, thus serving as a link between extrinsic and intrinsic pathways $[1,6,13]$. $t-B i d$, an active form situated on the mitochondrial membrane, is responsible for the intrinsic cascade via the activation of pro-apoptotic multi-domain Bcl-2 proteins Bax and Bak [6]. Activated Bax and Bak mediate increasing MOMP through the formation of pores and change of the mitochondrial membrane potential $(\Delta \Psi \mathrm{m})$, resulting in the release of cytochrome $\mathrm{c}[2,7,9,13]$. Cytochrome c, Apaf 1 protein, and procaspase- 9 form an apoptosome, enhancing the apoptotic cascade through activation of executioner caspases [7].

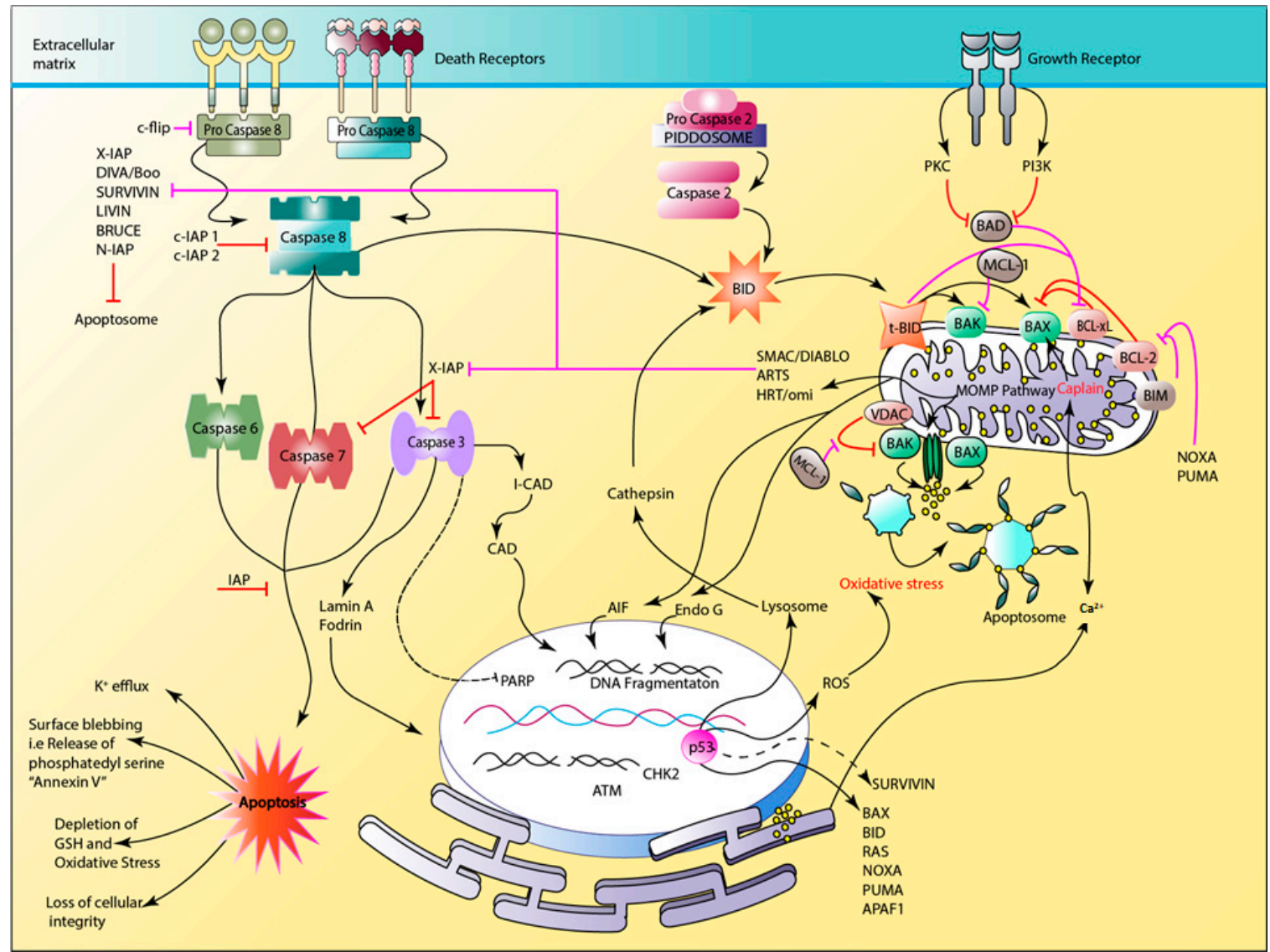

Figure 3. Illustration of intrinsic, extrinsic, mitochondrial, and endoplasmic reticulum apoptotic pathways. The role of apoptotic proteins (black arrows), and their inhibition by anti-apoptotic proteins (Red) which are regulated by apoptotic inhibitors (Pink). An apoptotic cell is usually characterized by increased $\mathrm{K}^{+}$efflux, surface blebbing, depletion of anti-oxidative markers such as GSH, chromatin condensation, and loss of cellular integrity.

Mitochondrial pores also facilitate the release of Smac/Diablo and Hrt/Omi which are BIR family inhibitors acting via inhibition of caspase-9 [14]. Intrinsic pathway could also be activated internally through oxidative stress, hypoxia, increased intracellular concentration of intracellular 
calcium ions, infection, or withdrawal of growth factors that obstruct the pro-apoptotic Bad protein that also stimulates Bax and Bak [7]. The activation of Bax and Bak is mediated through the inhibition of anti-apoptotic proteins Bcl-xL and Bcl-2 [6]. The function of Bak is restricted via VDAC. The activation of IAPs occurs as a result of the overexpression of tumor suppressor gene TP53 resulting in the activation of pro-apoptotic BH3 only domain proteins Bid (inhibiting Bcl-xL), Noxa (inhibiting Bcl-2) and Puma (inhibiting Mcl-1), all contributing to Bax-Bak pore formation and the release of cytochrome c. p53 functions in the process of ROS induction and increase of cellular stress as it was proven that ROS could enhance caspase function. ROS also stimulates $\mathrm{H}_{2} \mathrm{O}_{2}$ production, shifts the intracellular $\mathrm{pH}$, and favors the activation of Bak. In addition, $\mathrm{O}_{2}{ }^{-}$modulates the function of VDAC, hence increases mitochondrial membrane permeability [7]. p53 is also associated with lysosomal permeabilization, releasing cathepsin that activates Bid and Bak on the mitochondrial membrane [14,15]. Moreover, p53 is related to the activation of procaspase-2 through its release from p53-induced protein with a death domain PIDDOSOME. Subsequently, caspase-2 enhances the activation of $\mathrm{t}$-Bid, boosting the mitochondrial amplification loop $[15,16]$. The MOMP pathway activates AIF and Endo G that increase DNA fragmentation [7,14]. Moreover, the release of Smac/Diablo inhibits the function of BIR domain family, preventing the inhibition of caspase 9 [7]. Cytochrome $\mathrm{c}$ factors in the release of $\mathrm{Ca}^{2+}$ ions through the activation of Inositol 1,4,5 phosphate on the surface of the ER to mitochondria resulting in accumulation of $\mathrm{Ca}^{2+}$ in mitochondrial space, hence increasing mitochondrial stress and pore formation [14,17]. Increased intracellular $\mathrm{Ca}^{2+}$ ion concentration also triggers the activation of calpain, an intracellular endonuclease that targets the decomposition of nuclear and cellular membranes [18,19]. In addition to function of caspase- 3 in mitochondrial loop amplification, caspase- 3 is also considered to be an executioner caspase, inhibiting and cleaving PARP associated with DNA repair process. PARP activates CAD which contributes to DNA fragmentation, as well as activation of Lamin A, resulting in chromatin condensation and nuclear membrane degradation. Inter alia, the formation of apoptotic bodies is realized after activation of fodrin $[1,6]$. Already mentioned reactions/pathways lead to characteristic physiological and morphological alterations such as cell shrinkage and blebbing (pyknosis), formation of apoptotic bodies, and membrane changes influenced by the phosphatidyl serine "Annexin V" allowing phagocytic cells to attack [8,9]. Accordingly, chromatin condensation (karyorrhexis), DNA fragmentation, breakdown of nuclear membrane, and increase of mitochondrial membrane permeability as well as high consumption of ATP are included in such alterations $[1,8,9,18]$.

Cancer cells show resistance to apoptosis mediated by over expression of oncogenic genes (such as $c-M y c$, which enhances cellular proliferation and suppresses p53), and anti-apoptotic proteins (Bcl-2, survivin, livin, etc.) [9]. In contrast, the resistance of cancer cells to apoptosis can be also modulated via down regulation of pro-apoptotic proteins (caspases, Bad, Bax etc.) and the loss of tumor suppression function of p53 [1,7]. Overcoming resistance in apoptotic pathways is an interesting approach in cancer treatment [7]. This is mainly achieved through targeting p53 (drug, gene and immunotherapy), caspases (drug and gene therapy) and BIR family, and stimulating the action of IAP. Recently, plant-based treatment of cancer has been a highly active area of research across the globe. In this review, effects of flavonoids in cancer treatment and their influence on apoptotic pathways will be discussed.

\section{Phytochemicals}

\subsection{Classification of Phytochemicals}

Phytochemicals are bioactive non-nutrient compounds widely distributed in plants with an ability to reduce the risk of various diseases [20,21]. There are more than 50,000 different known phytochemicals in plant kingdom. The basic classification of phytochemicals is provided in Figure 4 .

Significantly, phenolics possess one or more aromatic benzene ring and could be mono or poly hydroxylated. Moreover, phenolics are considered to be the most abundant antioxidants in human 
diet. Phenolics are classified as non-flavonoids including phenolic acids, stilbenes, tannins, coumarins, and flavonoids [22].

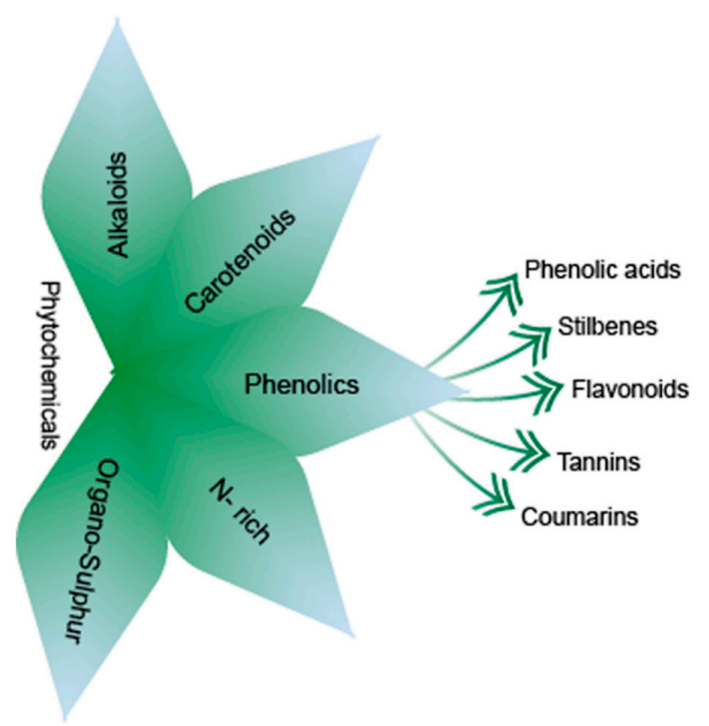

Figure 4. Classification of phytochemicals. alkaloids, carotenoids, n-rich, organo-sulphur compounds, and phenolics, which are further classified as phenolic acids, stilbenes, flavonoids, tannins, and coumarins.

\subsection{Flavonoids}

Flavonoids are secondary plant metabolites responsible for color and aroma of flowers, and they possess antibacterial, antiviral, antioxidant, anti-allergic, and anti-inflammatory abilities [20,23,24]. In the process of carcinogenesis, flavonoids interfere with multiple signal transduction pathways and thus limit proliferation, angiogenesis, and metastasis or increase apoptosis [25] (Figure 5A,B).

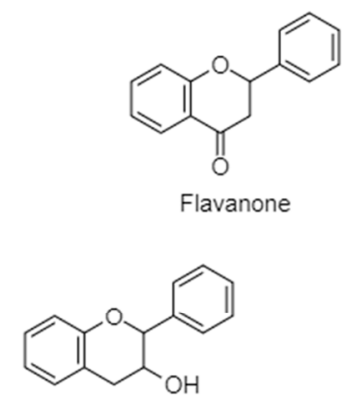

Flavanol<smiles>O=c1c(O)c(-c2ccccc2)oc2ccccc12</smiles>

Flavonol

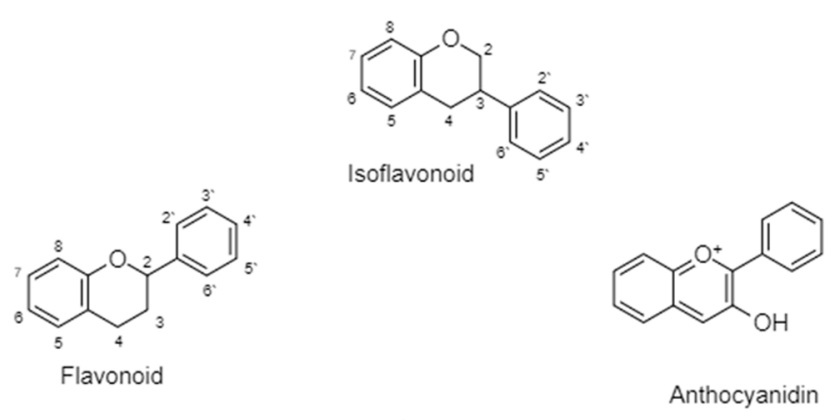

(A)

Figure 5. Cont. 


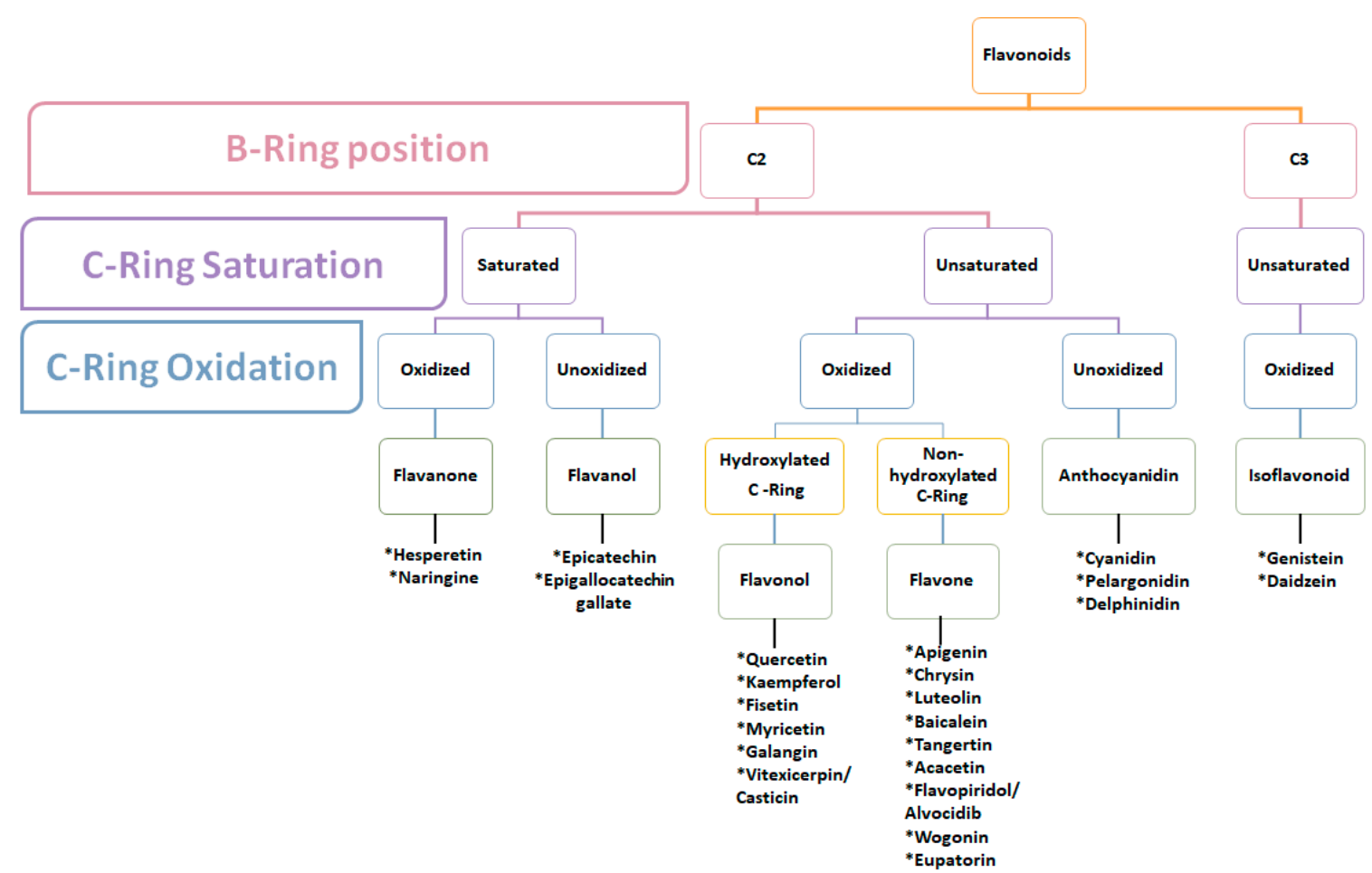

(B)

Figure 5. (A) Classification of flavonoids into six classes depending on structural differences: flavonol, flavanone, flavanol, flavone, anthocyanidin, and isoflavonoid. (B) Structural classification of plant flavonoids according to the position of B-ring on C2 or C3, B-ring saturation and oxidation.

Polyphenolic terpenoids consist of 15 carbon atoms arranged as a chromane ring (A and C) linked to a B ring in either C2 (Flavonoids) or C3 (isoflavonoids) [20,23]. As illustrated in Figure 5A,B, they could be further classified according to the $C$ ring saturation and oxidation into 5 major classes [20,24,25]. Each class differs in the degree of hydroxylation and substitution [22]. Flavonoids exist either as glycosides with attached sugars or as aglycones with no attached sugars [26].

\subsubsection{Flavonoids (B Ring Attached to C2)-Saturated C-Ring}

\subsubsection{Flavanone}

Flavanones, also known as di-hydroflavones, are characterized by a saturated, oxidized C ring. Flavanones are distributed in citrus fruits and are known for their antioxidant activity and free radical scavenging ability [20]. Hesperetin and naringenin are two main flavanone compounds (Figure 6).<smiles>COC1=CC[C@@H]([C@H]2CC(=O)c3c(O)cc(O)cc3O2)C=C1O</smiles>

Hesperetin<smiles>O=C1CC(c2ccc(O)cc2)Oc2cc(O)cc(O)c21</smiles>

Naringenin

Figure 6. Flavanones. Hesperetin and naringenin.

(A) Hesperetin

Hesperetin or 5,7,3'-trihydroxy-4'-methoxyflavanone is an aglycon present abundantly in citrus fruits, cherries, and tomatoes. Hesperetin and its glycoside, hesperidin, are known for 
their neuroprotective, vascular, anti-inflammatory, anti-allergic, antioxidant, and anticarcinogenic effects $[27,28]$. Hesperetin exerts anticancer abilities either by elevating ROS, attenuating mitochondrial potential, inducing DNA fragmentation, or by over expressing Fas and FADD ligands [29]. Pro-apoptotic effects of hesperetin were evaluated by both in vitro and in vivo studies. Hesperetin induced expression of cytochrome c, APAF-1, caspases-3 and -9 and reduced Bax to Bcl-2 ratio in gastric cancer cells [29]. Hesperetin was also found to induce cellular cell death in Eca109 cells by increasing ROS and decreasing GSH concentrations, confirming intrinsic mitochondrial cell death [30]. Similar pro-apoptotic effects were related to HT-29, MCF-7, and MDA-MB-231 cells [31,32]. Moreover, in the HT-20 cell line, hesperetin decreased the concentration of enzymatic antioxidants such as SOD, CAT, and GPx [32]. Conversely, in H522 cells, hesperetin induced apoptosis extrinsically via overexpression in Fas and FADD ligands, increase in caspase-9, and downregulation of p53 levels [33]. Furthermore, hesperetin was found to induce intrinsic and/or extrinsic apoptosis and cell cycle arrest at G2/M phase in the SiHa cell lines [34]. In addition to the inhibition of NF- $k B$ pathway, hesperetin reduced Bcl-2 transcription and translation in PC-3 cell lines [35].

(B) Naringenin

$5,7,4^{\prime}$-trihydroxyflavanone, also known as naringenin, is an aglycone found mostly in oranges and grapefruits. It has a broadly remarkable pharmacological profile and a wide range of biological effects, including anticancer, antioxidant, antimutagenic, antiproliferative, and anti-inflammatory abilities [36]. Anticancer properties of naringenin are induced either by elevating ROS, reducing mitochondrial potential, inducing DNA damage, or extrinsically by overexpression of Fas and FADD ligands. In a study conducted on SGC-7901 cells, naringenin induced apoptosis via increase in p53 expression, PARP cleaving, Bax and caspase- 3 cleaving, and also decrease in the expression of Bcl-2 and survivin $[37,38]$. Moreover, in A431 and HepG2 cells, naringenin arrested cell cycle at $G_{0} / G_{1}$ and/or $\mathrm{G}_{2} / \mathrm{M}$ phase, decreased $\Delta \Psi \mathrm{m}$, and increased the caspase-3 or Bax/Bcl-2 ratio. Considering HepG2 cells, in vivo studies revealed that naringenin increased cytochrome $\mathrm{c}$ and AIF/Endo G mobilization from the mitochondrial membrane, and reduced GSH concentration, SOC and, catalase activity [39-41]. Similarly, naringenin treatment of MCF-7 cell lines resulted in activation of caspase-3 [42]. Furthermore, a naringenin synthesized derivate (N101-2) induced cell cycle arrest at sub-G $\mathrm{G}_{1}$ phase in SiHa cells. Accordingly, intrinsic apoptosis was modulated due to elevated levels of p53, caspases-3, -8, and -9; increased PARP; and upregulation of Bax. On the contrary, extrinsic apoptotic pathway was confirmed by overexpression of Fas/FasL [43]. In HeLa and PC-3 cells, naringenin increased intracellular ROS level and induced loss of $\Delta \Psi \mathrm{m}[44,45]$.

\subsubsection{Flavanols}

Also known as catechins, flavan-3-ols are profoundly distributed in bananas, apples, peaches, pears, and blueberries [20]. Similar to flavanone, flavanol is characterized by a saturated $C$ ring. However, it is usually unoxidized and possesses a hydroxyl group at C3. Catechins can exert cell cycle arrest via modulation of multiple signaling pathways such as nuclear factor- $\mathrm{KB}, \mathrm{MAPK}$, epidermal growth factor, vascular endothelial growth factor, and matrix metalloproteinase. Flavanols are subdivided into epicatechin and epigallocatechin gallate (Figure 7). 
<smiles>Cc1cc(O)c2c(c1)OC(c1ccc(O)c(O)c1)C(O)C2</smiles>

Epicatechin<smiles>O=C(O[C@H]1Cc2c(O)cc(O)cc2O[C@H]1c1cc(O)c(O)c(O)c1)c1cc(O)c(O)c(O)c1</smiles>

Epigallocatechin Gallate

Figure 7. Classification and structure of flavanols.

(A) Epicatechin

Epicatechin is widely distributed in dark chocolate, grapes, and green tea. Epicatechin is known to be a potent antioxidant contributing to apoptosis and preventing angiogenesis by modulation of signaling enzymes activity Antiproliferative properties of epicatechin were observed in both HeLa and MKN-45 cells in which $\mathrm{H}_{2} \mathrm{O}_{2}$-mediated oxidative stress led to the rapid destruction of cancer cells [46]. The findings of other studies suggested that epicatechin is also able to target proliferative signaling Akt and NF- $\mathrm{kB}$. Interestingly, epicatechin in combination with panaxadiol or cisplatin showed synergistic pro-apoptotic effects in HCT-116 or renal tubular carcinoma respectively [47].

(B) Epigallocatechin Gallate (EGCG)

EGCG has been reported to induce apoptosis in many cancer cell lines. In prostate carcinoma cells EGCG considerably induced TRAIL-mediated apoptosis and, similarly, in small cell lung carcinoma EGCG increased caspase-3 activity [48]. Moreover, EGCG increased Bax/Bcl-2, p53, p21, caspases-3, and -9, PTEN and down-regulated PI3K, AKT, and Bcl-2 in T47D and HFF cells [49]. EGCG was also found to stimulate p21 and p27 expression in MDA-MB-468, MDA-MB-231 and HS578t cells, moreover, it inhibits Ki-67 in (PRB)-E2F/DP pathway [50]. Antiproliferative properties of EGCG were conducted on human esophageal squamous carcinoma cell lines in vitro and tumor xenografts in vivo. EGCG was found to exert cell cycle arrest at $\mathrm{G}_{1}$ phase in Eca-109 and Te-1 cells while the apoptosis was accompanied by elevated levels of ROS and caspase- 3 cleavage. Considering in vivo experiment, proliferation was inhibited via decrease in VEGF [51]. Moreover, in HT-29 cells EGCG induced apoptosis due to Akt, ERK1/2 or p38 MAPK inhibition [52]. Furthermore, pro-apoptotic effects of EGCG were demonstrated in 293T cells via modulation of Bax/Bcl-2, caspases, and cytochrome c release [53]. A dose-dependent cytotoxic effect of EGCG was observed in A549 cells due to the reduction of Bcl-xL [54]. Gupta, S. et al., reported that EGCG decreased cell proliferation in induced apoptosis via inhibition of the NF- $\mathrm{kB} / \mathrm{p} 65$ nuclear translocation [55,56]. In MCF-7 breast cancer cells EGCG inhibited the phosphorylation of ErbB2 and ErbB3 and suppressed the MAPK pathway [55,57], while in mammary tumor NF639 and SMF cells EGCG reportedly decreased cell proliferation, phosphorylation of ErbB2/neu and inhibited the NF-KB and MAPK pathways [55,58]. In SW837 colon cancer cells EGCG reportedly reduced the cellular levels of EGFR, ErbB2 and ErbB3 [55,59].

\subsubsection{Flavonoids (B Ring Attached to C2)-Unsaturated C-Ring}

\subsubsection{Flavonol}

Flavonol is characterized by the unsaturated $\mathrm{C}$ ring at $\mathrm{C} 2-\mathrm{C} 3$, which is found oxidized at $\mathrm{C} 4$ and hydroxylated at C3 [20]. Flavonol is widespread in kale, lettuce, onions, grapes, and berries. Flavonols are classified into six groups (Figure 8). 
<smiles></smiles><smiles>COc1cc(O)cc2oc(-c3cc(O)c(O)c(O)c3)c(O)c(=O)c12</smiles><smiles></smiles><smiles>O=c1c(O)c(-c2ccccc2)oc2cc(O)cc(O)c12</smiles><smiles>O=c1c(O)c(-c2ccc(O)c(O)c2)oc2cc(O)ccc12</smiles><smiles>COc1ccc(-c2oc3cc(OC)c(OC)c(O)c3c(=O)c2OC)cc1O</smiles>

Figure 8. Classification and structure of flavonols.

(A) Quercetin

$3,5,7,3^{\prime}, 4^{\prime}$-Pentahydroxyflavone or quercetin is the most abundant flavonoid, widely distributed in barks, flowers, and seeds of tomatoes, apples, berries, grapes, onions, tea leaves, Brassica vegetables, capers, shallots, and nuts [26,27]. Quercetin is a phytoestrogen structurally resembling endogenous estrogen $17_{\beta}$-estradiol [60]. Several studies support the anticancer potential of quercetin. In MCF-7 cells, quercetin showed the tendency to induce both apoptosis via increase of Bax, capsase-3 and decrease in Bcl-2 and necroptosis through overexpression of RIPK1 and RIPK3 [61,62]. Another study demonstrated the ability of quercetin to induce intrinsic mitochondrial apoptotic pathway [63]. On the contrary, quercetin enhanced extrinsic apoptosis in the BT-474 cell lines. Interestingly, it had no effect on Bcl-2 or Bax and therefore did not initiate any intrinsic apoptotic pathway [64].

Mitochondrial-induced pro-apoptotic effects of quercetin were demonstrated in HL-60 cell lines via modulation of Cox-2, caspase-3, Bax, Bad, Bcl-2, cytochrome c, and PARP [65]. In BC1, BC3 and BCBL lymphoma cells, quercetin induced apoptosis via downregulation of PI3K/AKT/mTOR and STAT3 pathways $[21,66]$. Quercetin in combination with EGCG reduced cell viability via inhibition of MDR1 in PC-3 and LNCaP cells. Moreover, effective reduction of LNCaP over PC-3 suggests that quercetin also mediates p53 apoptotic pathway $[23,67]$. In a similar manner when co-administered with metformin, quercetin inhibited the proliferative PI3K/AKT pathway [68]. While quercetin decreased ErbB2 tyrosine kinase activity and the phosphorylation of PI3K and AKT om SKBR3 breast cancer cells $[55,69]$, it reduced the phosphorylation of ERK1/2 and AKT phosphorylation and inhibited the NF- $\mathrm{BB}$ pathway in HepG2 liver cancer cells [55,70].

\section{(B) Kaempferol}

Kaempferol or 3,4,5,7-tetrahydroxyflavone is a nontoxic dietary flavonoid distributed in tea, kale, beans, onions, tomatoes, strawberries, broccoli, cabbage, apples, and grapes [71,72]. Kaempferol possess antioxidant, anti-inflammatory, antimicrobial, neuroprotective, and anticancer abilities. Kaempferol structurally resembles estrogen, thus it could have dual estrogenic/antiestrogenic effects depending on its concentration, and could be a candidate in treatment of hormonal based cancers such as ovarian, breast, and cervical; hepatocellular carcinoma; acute promyelocytic leukemia; and glioma $[71,73,74]$. In breast cancer MDA-MB-453 cells kaempferol induced DNA fragmentation and upregulation of p53 expression and phosphorylation leading to disrupting cell proliferative signaling, hence apoptosis [75]. Kaempferol was associated with the induction of intrinsic apoptosis in the A2780/CP70, A2780wt and OVCAR-3 cell lines via mitochondrial pathway in which increase of caspase-3, caspase-7, p53, Bax, Bad, and decrease in Bcl-xL was included. Kaempferol also decreased the proliferative signaling of Akt pathway and prevented angiogenesis via downregulation of VEGF [76]. Similar effects were observed in the case of HL-60 and NB-4 cells [77]. In another study, kaempferol synergistically increased the effect of cisplatin through overexpression of c-Myc in 
OVCAR-3 [78]. In HepG2 cells, kaempferol was found to induce apoptosis via ER stress and CHOP pathway [79]. Moreover, kaempferol enhanced apoptosis via mitochondrial membrane depolarization and down regulation of the expression of anti-apoptotic proteins x-IAP and survivin in A172 cells [80]. Additionally, in HeLa cell lines, kaempferol was associated with modulation of mitochondrial function and apoptosis via elevating the Bax/Bcl-2 ratio [81].

(C) Fisetin

$3,7,3^{\prime}, 4^{\prime}$-Tetrahydroxyflavone, also known as fisetin, can be found in strawberries, apples, persimmons, grapes, onion, and cucumber. Fisetin is reported to possess neurotrophic, anticarcinogenic, and anti-inflammatory properties [82]. Fisetin showed the tendency to induce apoptosis in the LNCaP cell lines via the induction of PARP cleaving, release of cytochrome c, cleavage of caspases-3, -8, -9, increase of Bad, Bax and Smac/Diablo and downregulation of Bcl-2, Bcl-xL and $\mathrm{x}$-IAP [83]. In DU145 and PC3 cells fisetin decreased the activity of NF- $\mathrm{kB}$. In addition, the co-treatment of cancer cells with TRAIL and fisetin caused significant activation of caspases- 3 and- 8 and disruption of the mitochondrial membrane [84]. Similarly, fisetin was associated with reduction of cell viability and induction of apoptosis in SNU-1 cell lines [85]. Fisetin exhibited similar effects in HeLa cells both in vitro and in vivo via modulation of $\Delta \Psi \mathrm{m}$, caspases-3, -8 , and Bax/Bcl-2 ratio leading to cleavage of PARP. Moreover, pro-apoptotic abilities were associated with fisetin in combination with sorafenib in xenografts [86,87]. Interestingly, fisetin induced ER stress mediated apoptosis in NSCLS [88]. Significantly, combinatorial treatment of fisetin and melatonin in MeWo and Sk-mel-28 cells resulted in cleavage of PARP protein, mitochondrial release of cytochrome-c, and inhibition of COX-2 and NF- $\mathrm{KB}$ proteins [89]. Furthermore, in U266 cells fisetin increased sub- $G_{1}$ population, caspase- 3 activation, over expression of Bax, Bim, and Bad; downregulation of Bcl-2 and Mcl-1; and continuous generation of $\operatorname{ROS}[21,90]$.

(D) Myricetin

$3,5,7,3^{\prime}, 4^{\prime}, 5^{\prime}$-Hexahydroxyflavoneis or myricetin is a common dietary flavonoid found black tea, green tea, or wine. Myricetin is associated with antibacterial, antiviral, antioxidant, and anti-carcinogenic activities [91]. Protective role of myricetin against cancer was demonstrated in HCT-15 cells by DNA condensation, suppression in Bcl-xL and Bcl-2 expression, and increase in the release of mitochondrial AIF. However, no effect on the cleavage of caspases-3 and -9 was observed [92]. In UVB induced HaCaT cells, myricetin exerted pro-apoptotic effects via inhibition of Akt pathway. Decrease in the Bad phosphorylation, $\Delta \Psi \mathrm{m}$ and release of cytochrome c, Smac, and AIF were also observed [93]. Furthermore, in SKOV3 cells myricetin induced nuclear chromatin condensation and fragmentation and DNA double strand breaks in dose-dependent manner [94]. In cisplatin resistant OVCAR-3 and A2780/CP70 cell lines myricetin overcame cancer chemoresistance and exhibited higher cytotoxicity than cisplatin. The underlying mechanism involved both intrinsic and extrinsic apoptotic pathways confirmed by regulated expression of Bcl-2 and DR5 respectively [95]. Finally, the mechanism of myricetin induced apoptosis in TNBC was comprehended by the induction of ROS that resulted in DNA double strand breaks, and activation of mitochondrial apoptotic pathway [96].

(E) Galangin

3,5,7-Trihydroxyflavone also known as galangin is highly concentrated in honey and propolis, and in the Chinese herb, lesser galangal. Findings of several studies suggested anticancer properties of galangin. The effect of galangin was tested on male and female human colon cancer cell lines HCT-15 and HT-29 respectively. Results illustrated caspase and mitochondrial dependent apoptotic pathways including DNA condensation, activation of caspases-3 and -9, release of AIF, and loss of mitochondria membrane potential [97]. In SNU-484 cells galangin induced apoptosis and inhibited cellular proliferation in both dose- and time-dependent manner. Changes in cell morphology, PARP cleavage, DNA fragmentation, activation of caspases-3 and -9, and MAP kinase pathway were all observed in treated cells [98]. In HepG2, Hep3B, and PLC/PRF/5by cell lines, galangin showed 
pro-apoptotic tendencies through translocation of Bax to the mitochondria, decrease in Bcl-2 expression, activation of caspase- 8 and Bid, release of cytochrome c, and PARP cleavage [99,100]. Moreover, pro-apoptotic effects of galangin in B16F10 cells were associated with disruption of $\Delta \Psi \mathrm{m}$ cleavage of procaspases-3 and -9 and PARP and p38 MAPK pathway [101]. Furthermore, galangin also reversed TRIAL resistance in Caki, ACHN, and A498 cells by downregulation of Bcl-2, c-FLIP, Mcl-1, and survivin, and inhibition of NF- $\mathrm{kB}$ pathway. Galangin in combination with berberine synergistically led to cell cycle arrest in Eca9706, TE-1 and EC109 cells at $\mathrm{G}_{2} / \mathrm{M}$ phase [102].

(F) Casticin (vitexicarpin)

$3^{\prime}, 5$-Dihydroxy-3,4',6,7-tetramethoxyflavone, or casticin, is well known for its strong pharmacological profile and use as an anti-inflammatory, neuroprotective, analgesic, immunomodulatory, and most importantly estrogenic and anti-carcinogenic agent $[103,104]$. In vitro investigation on human NSLC cell lines H460, A549 and H157 showed 50\% reduction of cell viability associated with membrane depolarization, mitochondrial release of cytochrome c, activation of caspases-3 and -9, increase of DNA fragmentation, downregulation of x-IAP and Bcl-xL proteins, and upregulation of Bax and Bid [105]. In BGC-823, SGC-7901, and MGC-803 cell lines and in human colon cancer HT-29, HCT-116, SW480, casticin induced apoptosis intrinsically by down regulation of c-FLIP, Bcl-2, x-IAP, and survivin. Extrinsic pathway was potentiated by TRAIL-induced cytotoxicity as it intensely upregulated DR5 receptor expression with no effects on DR4 or decoy receptors [106]. Treatment of PANC-1 cells and PC-3 cell lines with casticin led to the induction of apoptosis and cell cycle arrest via altering Bax/Bcl-2 ratio and activation of caspase $-3[107,108]$. Similar effects were observed in U251, U87, and U373 cells $[109,110]$. In xenografts of NOZ and SGC996 cells, casticin inhibited proliferation, induced apoptosis, and caused cell cycle arrest at $G_{0} / G_{1}$ via mitochondrial apoptotic pathway in which modulation of Bax, Bcl-2, cyclin D, caspase-3, -9, and PARP were observed [111].

\subsubsection{Flavones}

Flavones are distributed mainly in leaves, flowers, and fruits. Celery, parsley, mint, chamomile, red peppers, and ginkgo biloba are considered to be rich sources of flavones [20]. Similar to flavonols, their structure is comprised of an unsaturated $\mathrm{C}$ ring at $\mathrm{C} 2-\mathrm{C} 3$ position and a ketonic group at $\mathrm{C} 4$, but unlike flavonols they lack hydroxylation at C3 [20]. Flavones include apigenin, chrysin, luteolin, baicalein, tangertin, acacetin, flavopiridol/alvocidib, wogonin, and eupatorin (Figure 9).

\section{(A) Apigenin}

Apigenin or 5,7,4'-trihydroxyflavone is a phytoestrogen aglycone abundantly found in vine spinach, oranges, garlic, parsley, celery, carrot, propolis, artichokes, oregano, and chamomile. Apigenin anticancer efficacy in PC-3, 22Rv1, and DU145 cells resulted from the inhibition of HDAC enzymatic activity on transcriptional and translational levels leading to hyperacetylation of $\mathrm{H} 3$ on the $p 21 / w a f 1$ promoter. Correspondingly, Bax overexpression, knockdown of x-IAP, c-IAP1, c-IAP2 and survivin, Bcl-2 and Bcl-xL proteins, as well as the release of cytochrome $\mathrm{c}$ were also observed [112,113]. Moreover, in SCC25 and A431 cells, apigenin alone or in combination with 5-fluorouracil (5-Fu) or cisplatin led to cell cycle arrest at $\mathrm{G}_{2} / \mathrm{M}$ phase via augmenting levels of ROS, reducing glutathione, and inducing TNF-R and TRAIL-R [114]. Apigenin also suppressed ACHN, 786-0, and Caki-1 RCC cell proliferation in vivo through cell arrest at $\mathrm{G}_{2} / \mathrm{M}$ phase, DNA damage, and p53 upregulation [115]. In T24 cell line, apigenin inactivated PI3K/Akt pathway, cyclins phosphorylation of p53, p21 and p27, activated the caspase cascade, released cytochrome c, downregulated Bcl-xL, Bcl-2m Mcl-1 and upregulated Bax, Bad and Bak $[116,117]$. In SW480 xenograft model, apigenin induced alteration in expression of cyclin D1, BAG-1, Bcl-2, and FADD which led to apoptosis [118]. Moreover, in BCPAP cells, apigenin inhibited viability in a dose-dependent manner due to enhanced ROS and subsequent induction of DNA damage [119]. In HCT-116 cells, apigenin induced intrinsic, extrinsic, and ER stress-initiated apoptosis together with increase of ROS and decrease in mitochondrial membrane potential and $\mathrm{Ca}^{2+}$ 
generation. Apigenin upregulated protein expression of CHOP, DR5, BID, Bax, cytochrome c release, and caspase cascade $-3,-8$ and -9 [120]. Apigenin reportedly reduced ligand induced phosphorylation of EGFR and ErbB2 thereby impairing their downstream signaling and thus induces apoptosis in head and neck squamous carcinoma cells [121]. Additionally, apigenin inhibited the proliferation and survival of malignant mesothelioma cells in vitro, increased the intracellular production of reactive oxygen species and induced DNA damage [122]. The apigenin induced cell death was related to the increase in the Bax/Bcl-2 ratio, p53 expression, the activation of caspases 9 and 8 and cleavage of PARP-1 [122]. In an in vivo C57BL/6 mouse model of malignant mesothelioma transplanted with \#40a cells, intraperitoneal administration of apigenin reduced the risk of tumor growth and increased median survival rates in the apigenin treated mice [122]. Shukla, S. et al., reported that apigenin treatment decreased cell proliferation, increased proportion of cells in $G_{0} / G_{1}$ phase and decreased the levels of $\mathrm{Rb}$ and $\mathrm{p} 38$ kinase [55,123].<smiles>O=c1cc(-c2ccc(O)cc2)oc2cc(O)cc(O)c12</smiles>

Apigenin<smiles>O=c1cc(-c2ccccc2)oc2cc(O)c(O)c(O)c12</smiles>

Baicalein<smiles>COc1c(O)cc(O)c2c(=O)cc(-c3ccccc3)oc12</smiles>

Wogonin<smiles>COc1cc(-c2cc(=O)c3c(O)cc(O)cc3o2)cc(OC)c1O</smiles>

Chrysin<smiles>COc1ccc(-c2cc(=O)c3c(O)cc(O)cc3o2)cc1</smiles>

Acacetin<smiles>CN1CCC(c2c(O)cc(O)c3c(=O)cc(-c4ccccc4Cl)oc23)C(O)C1</smiles>

Alvocidib<smiles>O=c1cc(-c2ccc(O)c(O)c2)oc2cc(O)cc(O)c12</smiles><smiles>COc1ccc(-c2cc(=O)c3c(OC)c(OC)c(OC)c(OC)c3o2)cc1</smiles><smiles>CCOc1ccc(-c2cc(=O)c3c(O)c(OC)c(OC)cc3o2)cc1O</smiles>

Figure 9. Classification and structure of flavones.

(B) Chrysin

5,7-dihydroxyflavone, or chrysin, is a flavonoid abundantly found in Thai propolis and honey. Chrysin is an apigenin analogue with high therapeutic potential favorable to intestinal membrane transport. However, its low bioavailability due to rapid metabolism and excretion renders its use less beneficial when compared to other flavonoid compounds [124,125]. Chrysin demonstrated high potency as an aromatase inhibitor in addition to its well-known role as an anti-inflammatory, antioxidant, and cancer chemo-preventive agent [126]. Chrysin was reported to be the most potent flavonoid functioning in the reduction of cell viability and induction of apoptosis in HeLa cell lines via increased DNA fragmentation and induction of $\mathrm{p} 38$ and NF- $\mathrm{kB} / \mathrm{p} 65$. In Bcl-2 overexpressing U937 cell lines, chrysin showed pro-apoptotic effects through activation of caspase- 3 and increased degradation of PLC-1, in addition to downregulation of x-IAP and inactivation of Akt [126]. Moreover, TRAIL-induced apoptosis associated with chrysin was observed in A549 and HeLa cell lines. TRAIL-induced cell death was selectively induced via inhibition of STAT3 and knockdown of Mcl-1 [97]. TRAIL-induced cell death after chrysin treatment was also observed in HCT-116 and CNE1 cells [127]. Recently a fully elucidated mechanism was exploited in DU145 and PC-3 cells including loss of MMP, increase in ROS, ER stress, and suppression of PI3K [128]. In SP6.5 and M17 melanoma 
cultured cells, chrysin activated mitochondrial dependent apoptotic pathway via loss of membrane potential, cytochrome $\mathrm{c}$ release, and activation of caspases-3 and -9 but not -8 [129]. Chrysin alone or in combination with cisplatin in HepG2 and QGY7701 cancer cells induced intrinsic and extrinsic apoptotic pathways due to increased levels of p53, Bax, caspases-3, -8 , and -9 and DR5 along with decreased Bcl-2 levels [130,131].

(C) Luteolin

Luteolin or 5,7,3' $4^{\prime}$-tetrahydroxyflavone, is a well-known chemo-preventive, anti-inflammatory, and a cytotoxic chemotherapeutic agent $[21,132,133]$. In HepG2 cells, luteolin increased concentration of cytochrome c, translocated mitochondrial Bax and Bak and activated JNK pathway. In a tumor xenograft model, luteolin activated AMPK and NF- $\mathrm{kB}$ signaling and the release of ROS [134,135]. In NSLC A549 luteolin activated JNK, increased Bax, and promoted cleavage of caspases-3 and-9. Moreover, luteolin induced cytotoxicity, increased expression of p53 and p21, decreased MDM4 protein expression, and activated caspases-3 and -9 in vivo [136-138]. In NCI-H4 60 cells treated with luteolin apoptosis was modulated intrinsically, extrinsically, and via ER stress [139]. Similarly, ER stress and elevation of ROS in vitro and in vivo were observed in U251MG and U87MG cells [140]. The combination of luteolin with chemotherapeutic drugs 5-fluorouracil or gemcitabine synergistically induced anti-proliferative activity as reflected by decreased protein expression of nuclear GSK-3b and NF- $\mathrm{KB}$, and increased cytochrome c [141]. In PANC-1, CoLo-357, and BxPC-3 luteolin increased $\mathrm{Bax} / \mathrm{Bcl}-2$ ratio associated with an increase in caspase-3, cleavage of PARP, and inhibition of NF- $\mathrm{B}$ [136]. The Co-administration of luteolin and paclitaxel in MDA-MB-231 cells in mice xenografts resulted in reduction of tumor size via an increase in activated caspases- 3 and -8 and increased expression of Fas. Luteolin also inhibited metastatic breast cancer cell lines by reducing expression of VEGF $[142,143]$. Luteolin was reported to induce intrinsic and extrinsic apoptotic pathway in HeLa cells via enhancement of caspase- 3 and -8 activation cascade; reduction of $\Delta \Psi \mathrm{m}$ associated with a release of cytochrome c; inhibition of Bcl-2 and Bcl-xL expression; and upregulation of death receptors Fas/FasL, DR5/TRAIL, and FADD [144].

(D) Baicalein

5,6,7-Dihydroxyflavone, or baicalein, is an aglycone found abundantly in the root of S. baicalensis [145]. Baicalein is known for its extensive pharmacological anti-inflammatory, anti-cardiovascular, and anti neuro-degenerative effects. Its pro-apoptotic effect on cancer cells is both mitochondria and receptor mediated, accomplished mainly by modulation of Bcl-2 family [146,147]. In SCC-4 cells, baicalein elevated Bax and lowered Bcl-2, modulated the release of cytochrome c, and activated the caspase cascade. Moreover, baicalein increased DR5 and TRAIL at protein and transcription levels and also elevated the level of ROS and induced ER stress [147]. Similar anti-proliferative effects of baicalein were observed in PCa cells [148]. Furthermore, in BxPC-3 and PANC-1cell lines baicalein suppressed proliferation and metastasis through reduction of Akt and ERK activities [149]. In CRC HT-29 baicalein induced cell cycle arrest in the $\mathrm{G}_{1}$ phase, DNA fragmentation, chromatin condensation; decreased Bcl-2 and increased Bax expression; reduced MMP-9; and controlled Akt. In mice xenografts, baicalein modulated Akt and p53 dependent pathway and reduced expression of MMP 2/9 [150,151]. Baicalein treatment in SGC-7901 cells in vitro and in vivo through disruption of $\Delta \Psi \mathrm{m}$, modulation of Bax/Bcl-2 in a dose-dependent manner [152]. Furthermore, in MDA-MB-231 cells pro-apoptotic effects of baicalein were associated with disruption of mitochondrial potential, release of cytochrome c, activation of caspases-3 and -9, increased Bax/Bcl-2, and elevated p53 expression and elevated signaling of ERK/p38 MAPK pathway. In addition, baicalein significantly inhibited invasion and metastasis by reducing the expression of MMP-2/9 and downregulating MAPK [153]. Baicalein downregulated Bcl-2 and upregulated caspase-3, -8, Bax, and Fas/FasL in HeLa cells [154]. Additionally, baicalein induced ER stress; upregulated Bax; downregulated Bcl-2, and induced cleavage of caspases-3, -9, and PARP in HCC cells in vitro and 
in vivo [155]. Similarly, baicalein inhibited tumor cell proliferation and induced $G_{2} / M$ arrest in HCC J5 cells [153].

(E) Tangertin

5,6,7,8 4'-Pentamethoxyflavone, also known as tangertin, can be found in citrus peel oil of the tangerine and other citrus fruits [156]. Tangertin was found to reduce DMBA-induced oxidative stress in breast cancer Sprague-Dawley rats by decreasing antioxidant enzymes SOD, CAT, GPx, GST, GSH, ascorbic acid and $\alpha$-tocopherol [157]. In addition, tangertin was found to cause cell cycle arrest at $\mathrm{G}_{1} / \mathrm{S}$ phase via p53/p21 up-regulation, and inhibited metastasis by suppressing MMP-2 and -9 and vascular endothelial growth factor [158]. In AGS, in a dose-dependent manner, tangertin induced apoptosis via p53 dependent mitochondrial dysfunction and Fas/FasL extrinsic pathway. Tangertin also suppressed p53 inhibitor PFT- $\alpha$ via upregulation of p53, caspases-3, -8 , and -9 activity, and Bax, t-Bid, p53, Fas, and FasL [159]. Moreover, in U-87MG and LN-18 tangertin induced $\mathrm{G}_{2} / \mathrm{M}$ arrest and apoptosis by modulating PTEN and cyclin-D and cdc-2 mRNA and protein expressions [160]. Additionally, tangertin in combination with TRIAL in H1299 and H1975 cells downregulated anti-apoptotic Bcl-2, Bcl-xL, survivin, x-IAP, c-IAP1, and c-IAP2 and elevated expression of pro-apoptotic Bax and caspases-3, -8, and -9. In addition to a significant increase in expression of DR 4 and 5, induction of ER stress was mediated via upregulation of CHOP and elevation of ROS [161].

(F) Acacetin

Acacetin is 5,7-dihydroxy-4'-methoxyflavone extracted from safflower flowers. Acacetin is associated with anti-peroxidative, anti-inflammatory, anti-plasmodial, and anticancer effects $[162,163]$. In $\mathrm{T}$ cell leukemia Jurkat cells, acacetin induced apoptosis through alterations in nuclear and cell morphology; induction of caspases-3, -8, and -9 activity; release of Apaf- 1 and cytochrome c; and an increase in Bax/Bcl-2 ratio in a time-dependent manner [164]. The study conducted on the pro-apoptotic effects of acacetin in chronic lymphocytic leukemia (CLL) B-lymphocytes xenografts and healthy B-lymphocytes proved direct targeting of mitochondrial pathway via increased release of cytochrome c, caspase -3 activation, increased concentration of reactive oxygen species (ROS); and MMP collapse [165]. Acacetin showed antimetastatic potential in DU-145 cells via inhibition of phosphorylation of p38 MAPK involved in the knockdown of expression of MMP 2 and 9, and u-PA at protein and mRNA levels. In addition, acacetin was found to influence chromatin condensation and ability to significantly deplete nuclear NF- $\mathrm{BB}$, which is associated with downregulation of Bcl-2 and x-IAP and proliferative protein COX-2 [163,166]. Moreover, in MCF-7 and HSC-3 cell lines acacetin influenced growth inhibition, DNA fragmentation, and PARP cleavage; enhanced caspases-7, -8 and -9 activity; and decreased Bcl-2. Acacetin also decreased mitochondrial membrane potential, modulated release of AIF and cytochrome c, and enhanced ROS generation, which subsequently resulted in apoptosis [162,167].

\section{(G) Flavopiridol/Alvocidib}

Flavopiridol is a cyclin-dependent kinase inhibitor mainly targeting CDK 9 in phase II clinical trials. Flavopiridol has shown efficacy in the treatment of chronic lymphocytic leukemia (CLL) SU-DHL-4 and TMD8 cells. Generally, flavopiridol initiates cell cycle arrest and apoptosis in a p53-independent mechanism that involves the down regulation of anti-apoptotic Mcl-1 and X-IAP and induction of ER stress [168-171]. In HCC the inhibitory effect of flavopiridol was associated with Mcl-1 inhibition that enhanced caspase-3 activation and PARP cleavage [172]. Interestingly, doxorubicin applied in combination with flavopiridol in HCC mouse models significantly reduced proliferative signaling [173]. Moreover, the anti-proliferative and pro-apoptotic effects of the flavopiridol in combination with oxaliplatin in melanoma cells and its subcutaneously injected allograft were associated with enhanced caspase $-3,-7$ and -9 activities in a dose dependent manner via the mitochondrial apoptotic pathway [174]. In metastatic osteosarcoma U2OS, SaOS-2, SJSA-1, and 143B, 
at nanomolar concentrations flavopiridol treatment led to significant reduction of cadherin 3 and 4, thus reducing metastatic potential in lungs [175].

(H) Wogonin

Wogonin, or 5,7-dihydroxy-8-methoxyflavone, extracted from Scutellaria baicalensi is associated with antioxidant, anti-inflammatory, anticonvulsant, neuro-protective, anti-bacterial, and anti-viral effects. Wogonin in LNcaP cells elevated levels of p21, p27, p53 and PUMA, which are involved in apoptotic Bax signaling [176]. Interestingly, wogonin in SK-N-BE2 and IMR-32 cell lines influenced mitochondrial dysfunction and ER due to the release of cytochrome c; altered expression of Bcl-2, Bax, and Bid; activation of caspases-3, -4, -8, -9, and -12; increased PARP cleavage; and ER stress-related proteins GRP-78 and GRP-94 [177]. In NSLC A549 and HeLa cell lines synergetic effects of wogonin and cisplatin were observed via potentiation of caspase-3 activity, and subsequent cleavage of PARP and $\mathrm{H}_{2} \mathrm{O}_{2}$ accumulation [178]. The viability of HT-29 cells was suppressed in a dose-dependent manner after wogonin treatment via induction of cell cycle arrest at the $G_{1}$ phase; increased DNA fragmentation, chromatin condensation, and Bax/Bcl-2 ratio, inactivation of PI3K/Akt pathway; and upregulation and activation in a p53 [151]. In A2780 cells wogonin inhibited proliferation and metastasis via reduction of VEGF, Bcl-2 and Akt expression, and augmentation of Bax expression and p53 caspase-3 cleavage [179] Cytotoxic effects of wogonin were observed in HCC cell lines and xenografts via inactivation of AKT signaling, leading to the elevated levels of $\mathrm{H}_{2} \mathrm{O}_{2}$ and ER release of $\mathrm{Ca}^{2+}$ [180]. HPCC cells treatment of wogonin led to apoptosis due to enhanced ROS generation [181].

(I) Eupatorin

5,3'-Dihydroxy-6,7,4'-trimethoxyflavone, also known as eupatorin, is isolated from Orthosiphonstamineus, leaves of Lantana montevidensis, and in the aerial plants of Tanacetum vulgare. Eupatorin showed inhibitory effects on MDA-MB-468 cell lines at sub micromolar concentrations and in a dose dependent manner. Eupatorin led to cell cycle arrest at $\mathrm{G}_{2} / \mathrm{M}$ phase. The mechanism was elucidated by the selective activation of metabolic pathway of CYP1 to a cytotoxic active ingredient [182]. Similarly, induction of cell cycle arrest at $G_{2} / M$ phase was also reported in HeLa cells. In addition to activation of BAX in a p53 independent pathway, Eupatorin upregulated p53, p21 caspases-3 and -7, and PARP cleavage [183]. In HT-29 and SW948 cell lines, eupatorin decreased cell viability and induced apoptosis via a decrease in mitochondrial membrane potential, accompanied by an increase in Bax/Bcl-2 expression and an increase in ROS levels [184]. Treatment of eupatorin in combination with doxorubicin in colon cancer simultaneously increased the Bax/Bcl-2 ratio, caspase-3 expression, and PARP cleavage and induced apoptotic cell death [185]. In human leukemic cells it induced apoptosis via mitochondrial release of cytochrome c, activation of multiple caspases, and PARP cleaving [186]. Finally, the induction of apoptosis and cell cycle arrest in HepG2 was effectively induced via modulation of p53, MAPKs, and the mitochondrial pathways [187].

\subsubsection{Anthocyanidins}

Anthocyanidins are characterized as a water-soluble, unsaturated, unoxidized class of flavonoids, occurring as plant pigments responsible for plant coloration depending on $\mathrm{pH}$ which contributes to their attractiveness.

The antioxidant activity of anthocyanins is based on their phenolic structure and multiple hydroxylation in position 3 of ring $C$ and in the $3^{\prime}, 4^{\prime}$ and $5^{\prime}$ positions in ring $B$ of the molecule (Figure 10). Anthocyanidins (Figure 10) are associated with reduction of DNA damaging oxidative adducts, diminishing lipid peroxidation, inhibiting mutagenesis, and modulating signaling cascades, thus reducing cellular proliferation. Aglycons are usually more potent antioxidants owing to fewer number of sugar groups $[188,189]$ exhibiting wide pharmacological effects on cardiovascular disease and obesity, and antitumor, anti-inflammation, and anti-mutagenesis activities [190]. 


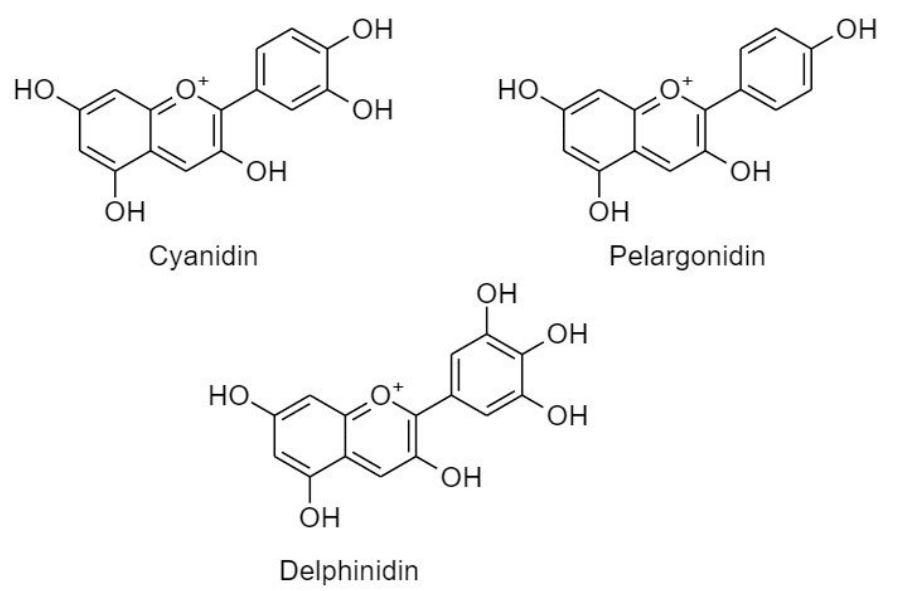

Figure 10. Classification and structures of anthocyanidins.

(A) Cyanidin

Cyanidin is usually found conjugated to a sugar, e.g., cyanidin-3-O- $\beta$-glucopyranoside (C3G). It has shown great effects in inducing cell cycle arrest, inhibiting proliferation (by impeding VEGF), metastasis (by the inhibition of MMP 2 and 9), and enhancing apoptosis caspase-independent AIF pathway (by activating cytochrome $\mathrm{c}$ and Bax protein expression) in various cancer cell lines [191]. Antiproliferative effect of C3G in DU145 and LnCap cell lines was mediated through activation of caspase-3 and induction of p21 protein expression, along with an increase in DNA fragmentation and levels of tumor suppressor P75NGFR [192]. In U87 cells, C3G showed pro-apoptotic effects via elevation of RNA expression of Bax and p53, whereas the expression of Bcl-2 was decreased [193].

Similarly, in MCF-7 cells, C3G mediated apoptosis via influencing morphological changes, surface blebbing, and nuclear condensation [194]. Cyanidin induced apoptosis in RCC by enhancing caspase-3, inhibited metastasis via inhibition of E-cadherin, and inhibited tumor growth of nude mice xenografts [195]. Cell cycle arrest at $\mathrm{G}_{2} / \mathrm{M}$ phase and DNA fragmentation were observed in U937 after cyanidin treatment [196]. Finally, cyanidin-3,5-diglucoside, cyanidin-3-glucoside, cyanidin-3-rutinoside, and peonidin-3-glucoside blocked SMMC-7721 cells in vitro and H22 cells in vivo via inducing cell cycle arrest at $\mathrm{G}_{2} / \mathrm{M}$, DNA damage, increase in the activities of antioxidase, and a decrease in the level of lipid peroxidation [197].

(B) Pelargonidin

Pelargonidin is an anthocyanidin that is abundant in berries [198]. The acylated pelargonidin derivatives displayed a cytotoxic effect in Bel-7402 cells in a concentration-dependent manner associated with its antioxidant and pro-oxidant properties, along with influence on DNA damage [199]. Pelargonidin-glucoside in HT-29 induced apoptosis via activation of caspase-3 [188]. Correspondingly, pelargonidin exposure to HT-29 cells caused the release of cytochrome c from mitochondria; upregulated the activities of caspase- 3 and -9 , Bax, and Bid; downregulated the expression of Bcl-2 and Bcl-xL in addition to cleavage of PARP; and induced the expression of p53 and p21waf1 I [198]. Moreover, in U2OS cell line, pelargonidin triggered ROS-induced reduction in MMP and led to $\mathrm{G}_{2} / \mathrm{M}$ cell cycle arrest. In addition, pelargonidin also reduced the expression of proliferative cascades p-PI3K and p-AKT in a concentration-dependent manner [200].

(C) Delphinidin

Delphinidin is a major anthocyanidin found profusely in various colored fruits and vegetables, such as red cabbage, berries, sweet potatoes, and grapes. Delphinidin possesses anti-angiogenic, anti-inflammatory, anti-mutagenic, antioxidant, and anti-tumorigenic abilities [201,202]. In SKOV3 cells, delphinidin reduced proliferation in a dose dependent manner through inactivation of PI3K/AKT and ERK1/2 mitogen-activated protein kinase signaling cascades [202]. Similarly, in NSCLC 
delphinidin inhibited the activation of PI3K, phosphorylation of AKT and MAPKs; cleavage of PARP; activation of caspases-3 and -9; downregulation of Bcl-2, Bcl-xL, and Mcl-1; and upregulation of Bax and Bak. In mice xenografts significant inhibition of tumor growth along with an obvious decrease in cell proliferation markers Ki67, PCNA, and angiogenesis CD31, VEGF were also observed after the treatment [203]. Furthermore, in B CLL, delphinidin-3-O-glucoside and delphinidin-3-O-rutinoside demonstrated pro-apoptotic effects through a redox-sensitive caspase -3 activation mechanism as well as dysregulation of the Bad/Bcl-2 pathway, by rapidly dephosphorylating Akt and Bad and downregulating Bcl-2 [204]. Additionally, delphinidin induces apoptosis and cell cycle arrest in highly metastatic human prostate cancer PC3 cells and androgen refractory human prostate cancer 22Rnu1 cells through the inhibition of several components of NF-kB pathway $[55,205,206]$. Intra-peritoneal administration of delphinidin $(2 \mathrm{mg})$, thrice a week, significantly reduced tumor growth in athymic nude mice implanted with PC3 cells (an in vivo model of prostate cancer). Investigations revealed that treatment with delphinidin significantly decreased the expression of NF- $\mathrm{kB} / \mathrm{p} 65$, anti-apoptotic Bcl2, Ki67 and PCNA in these tumors $[55,206]$.

\subsubsection{Isoflavonoids (B Ring Attached to C3)}

Distribution of isoflavonoids in plants is limited to soybeans and legumes, but they were also found in some microbes [20]. Isoflavonoids are further subdivided into genistein and daidzein (Figure 11). High consumption of isoflavonoids was correlated with decreased risk of estrogen related cancers [23] due to its estrogenic activity and ability to compete with $17_{\beta}$-estradiol in vitro and in animal models [20,73]. It was also confirmed that isoflavones exert DNA photoprotective effects and upregulates the expression of glutathione peroxidase enzyme [27].

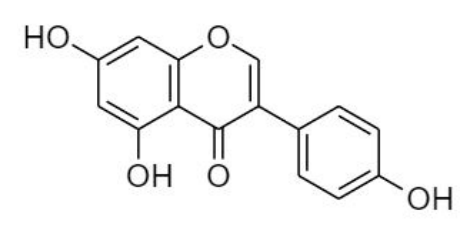

Genistein

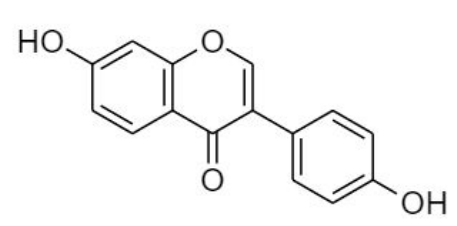

Daidzein

Figure 11. Classification and structure of isoflavonoids.

(A) Genistein

Genistein or 5,7,4'-trihydroxyisoflavone, is a phytosterol found profusely in soybeans [207,208]. Genistein affected proliferation, differentiation, and apoptosis in MCF-7 and 3T3-L1 cells via regulating estrogen receptor- $\alpha(\mathrm{ER} \alpha)$ expression and altering Bax/Bcl-2 ratio [21,209]. Cytotoxic action of genistein against MDA-MB cells involved prooxidant signaling due to the mobilization of endogenous copper Notch-1 pathway which resulted in inhibition of NF-KB activity, and downregulation of Bcl-2 and Bcl-xL [210,211]. Moreover, in A2780, C200 cells genistein downregulated Bcl-2, Bcl-xL, c-IAP1, survivin, and NF- $\mathrm{KB}$ [212]. In LNCaP cells genistein induced apoptosis via augmented TRAIL-induced disruption of mitochondrial membrane potential [213]. The combination of Daidzein and genistein showed a synergistic effect on inhibition of cell proliferation and inducement of apoptosis in LNCaP and C4-2B [214]. Similarly, combination of genistein and selenium in PC3 and LNCaP (hormone-dependent) significantly inhibited growth and metastasis in dose- and time dependent manner by decreasing the expression of in MMP-2, which has been associated with active invasion and metastasis [215]. In HT-29 cell lines, the effect of genistein was explained by activating and dephosphorylating tumor suppressor FOXO3, which is usually attenuated by EGF [216]. The potency of genistein against HT-29 colon cancer showed that apoptosis was induced by increased caspase- 3 activity at the transcriptional, protein, and enzymatic levels and reduced matrix metalloproteinase-2 (MMP2) activity [217] while it acted by inducing the mitochondrial pathway of apoptosis in HCT-116 and LoVo cells by inhibiting phosphorylation of Akt [218]. 
(B) Daidzein

7,4'-Dihydroxyisoflavone, also known as daidzein, is a dietary phytoestrogen isolated from soybeans. It is structurally similar to genistein; however, it lacks the hydroxyl group at position 5 [208]. Daidzein showed antiproliferative effects in different cancer cell lines. In MCF-7 cells and xenografts in a concentration- and time-dependent manner, daidzein stimulated production of ROS; release of cytochrome $\mathrm{c}$ from the mitochondrial membrane; activation of caspases-7 and -9; and alteration in Bax/Bcl-2 ratio [219,220]. Daidzein was also involved in induction of apoptosis in HCCSK-HEP-1, associated with up-regulation of Bak and down-regulation of Bcl-2 and B-xL proteins; release of mitochondrial cytochrome c; APAF-1; and activation of caspases-3 and -9 [221].

\section{Final Remarks, Future Perspectives and Conclusions}

Plant extracts have been proven to be strong candidates in the treatment of various types of cancer via modulating apoptotic pathway. The major mechanism involves the activation of apoptotic proteins intrinsically and extrinsically, elevation of ROS, and induction of DNA damage. The $\mathrm{IC}_{50}$ values of the various flavonoid compounds for various cancers discussed in the current manuscript is provided in Table 1.

Table 1. $\mathrm{IC}_{50}$ values of various flavonoids in different types of cancer.

\begin{tabular}{|c|c|c|c|c|}
\hline Compound & Cancer Type/Cell Line & Time Point (h) & $\mathrm{IC}_{50}$ & Reference \\
\hline Hesperetin & Myeloid & 24 & $500 \pm 100 \mu \mathrm{M}$ & [222] \\
\hline Naringenin & Lymphoid & 48 & $164.9 \pm 21.83 \mu \mathrm{M}$ & [222] \\
\hline \multirow{6}{*}{ EGCG } & Breast T47D & 72 & $14.17 \mu \mathrm{M}$ & [49] \\
\hline & Prostrate LNCaP & 48 & $0.4 \mu \mathrm{M}$ & [223] \\
\hline & Prostrate PC3 & 48 & $38.95 \mu \mathrm{M}$ & [224] \\
\hline & Lung & 24 & $70 \mu \mathrm{M}$ & [225] \\
\hline & Bladder & & $70-80 \mu \mathrm{M}$ & [226] \\
\hline & $\begin{array}{l}\text { Acute T-lymphoblastic } \\
\text { leukemia (CCRF-CEM) }\end{array}$ & & $16.04 \pm 1.56 \mu \mathrm{M}$ & [227] \\
\hline Quercetin & Bladder & 48 & $876.9 \pm 13.1 \mu \mathrm{M}$ & [222] \\
\hline Kaempferol & Bone & 24 & $148.4 \mu \mathrm{M}$ & {$[222]$} \\
\hline Fisetin & Erythroid & 48 & $15 \pm 2 \mu \mathrm{M}$ & [222] \\
\hline Myricetin & Colon & 72 & $68.0 \pm 20.4 \mu \mathrm{M}$ & {$[222]$} \\
\hline Galangin & Liver & 24 & $100.4 \pm 17.0 \mu \mathrm{M}$ & [222] \\
\hline \multirow{5}{*}{ Casticin } & Lung A549 & 48 & $0.4 \mu \mathrm{Mol} / \mathrm{L}$ & [228] \\
\hline & $\begin{array}{l}\text { Actute T-lymphoblastic } \\
\text { leukemia (CCRF-CEM) }\end{array}$ & $24 \& 72$ & $0.28 \pm 0.02 \mu \mathrm{M}$ & [227] \\
\hline & Leukemia K562 & 48 & $5.95 \mu \mathrm{M}$ & [229] \\
\hline & Leukemia Kasumi-1 & 48 & $15.56 \mu \mathrm{M}$ & [229] \\
\hline & Leukemia HL-60 & 48 & $4.82 \mu \mathrm{M}$ & [229] \\
\hline Apigenin & ER- breast & 24 & $60.4 \pm 15.8 \mu \mathrm{M}$ & [222] \\
\hline Chrysin & ER+ breast & 48 & $82.5 \mu \mathrm{M}$ & {$[222]$} \\
\hline Luteolin & Lung & 72 & $35.9 \pm 9.3 \mu \mathrm{M}$ & [222] \\
\hline Baicalein & Stomach & 72 & $64.3 \mu \mathrm{M}$ & [222] \\
\hline Tangertin & Melanoma & 48 & $0.3 \mu \mathrm{M}$ & [222] \\
\hline
\end{tabular}


Table 1. Cont.

\begin{tabular}{|c|c|c|c|c|}
\hline Compound & Cancer Type/Cell Line & Time Point (h) & $\mathrm{IC}_{50}$ & Reference \\
\hline \multirow{3}{*}{ Acacetin } & Oral squamous HSC-3 & 24 & $25 \mu \mathrm{g} / \mathrm{mL}$ & [162] \\
\hline & MCF7 & 24 & $26.4 \pm 0.7 \mu \mathrm{M}$ & [167] \\
\hline & Melanoma & & $0.79 \mathrm{mM}$ & [230] \\
\hline \multirow{8}{*}{ Flavopiridol } & Bladder RT4/RTI12 & $24-72$ & $150-350 \mathrm{nM}$ & [231] \\
\hline & Bladder T24/SUP & $24-72$ & $1000 \mathrm{nM}$ & [231] \\
\hline & GCT & 72 & $60-70 \mathrm{nM}$ & [232] \\
\hline & SKOV, MCF-7, HeLa & 72 & $280-350 \mathrm{nM}$ & [232] \\
\hline & Esophageal & 72 & $100-150 \mathrm{mM}$ & [233] \\
\hline & HNSCC tumor xenografts & 10 weeks & $5 \mathrm{mg} / \mathrm{kg} /$ day & [234] \\
\hline & Hematopoietic SUDHL4 & 12 & $120 \mathrm{mMol} / \mathrm{L}$ & [235] \\
\hline & Prostrate PC3 & 12 & $203 \mathrm{mMol} / \mathrm{L}$ & [235] \\
\hline Wogonin & Ovarian & 72 & $19.9 \pm 1.2 \mu \mathrm{M}$ & [222] \\
\hline \multirow{8}{*}{ Eupatorin } & HeLa & & $11.72 \pm 2.86 \mu \mathrm{M}$ & [236] \\
\hline & K562 & & $4.29 \pm 1.35 \mu \mathrm{M}$ & [236] \\
\hline & MCF7 & & $16.61 \pm 5.56 \mu \mathrm{M}$ & [236] \\
\hline & RPMI8226 & & $4.77 \pm 0.51 \mu \mathrm{M}$ & [236] \\
\hline & HL-60 & & $14.09 \pm 0.55 \mu \mathrm{M}$ & [236] \\
\hline & MOLT & & $4.74 \pm 0.43 \mu \mathrm{M}$ & [236] \\
\hline & MDA-MB-468 & 96 & $0.5 \mu \mathrm{M}$ & [182] \\
\hline & MCF-7 & 96 & $50 \mu \mathrm{M}$ & [182] \\
\hline Cyanidin & HL-60 & 48 & $31.6 \mu \mathrm{M}$ & [237] \\
\hline \multirow{3}{*}{ Pelargonidin } & HL-60 & 48 & $85.2 \mu \mathrm{M}$ & [237] \\
\hline & Osteosarcoma U2OS & & $15 \mu \mathrm{M}$ & [200] \\
\hline & HepG2 & 24 & $33 \mu \mathrm{M}$ & [238] \\
\hline \multirow{2}{*}{ Delphinidin } & HepG2 & 24 & $77 \mu \mathrm{M}$ & [238] \\
\hline & HL-60 & 48 & $10.9 \mu \mathrm{M}$ & [237] \\
\hline \multirow{7}{*}{ Genistein } & Hepatocellular Hepa1-6 & 24 & $20 \mu \mathrm{M}$ & [239] \\
\hline & Pancreatic Mia-PaCa2 & 24 & $20 \mu \mathrm{M}$ & [240] \\
\hline & Pancreatic PANC-1 & 24 & $25 \mu \mathrm{M}$ & [240] \\
\hline & Pancreatic H6C7 & 24 & $120 \mu \mathrm{M}$ & [240] \\
\hline & Colorectal HCT 116 & 24 & $690 \mu \mathrm{M}$ & [217] \\
\hline & Colorectal HCT 116 & 48 & $135 \mu \mathrm{M}$ & [217] \\
\hline & Colorectal HCT 116 & 72 & $61 \mu \mathrm{M}$ & [217] \\
\hline \multirow{4}{*}{ Daidzein } & Colorectal HT-29 & 48 & $200 \mu \mathrm{M}$ & [241] \\
\hline & MIA PaCa-2 & 48 & $200 \mu \mathrm{M}$ & [241] \\
\hline & Ovarian SKOV3 [224] & 24 & $20 \mu \mathrm{M}$ & [242] \\
\hline & BEL-7402 & 48 & $59.7 \pm 8.1 \mu \mathrm{M}$ & [243] \\
\hline
\end{tabular}

\subsection{Bioavailability}

Bioavailability is the quantity of a compound that is absorbed and metabolized in the human body after it is ingested, and is commonly measured in terms of maximum plasma concentration (Cmax) [55]. 
Epidemiological data revealed an association between a diet rich in flavonoids and the prevention of human diseases. The efficacy of flavonoid compounds as cures and protective agents against a variety of human disease was tested extensively in in vitro experimental models and there remains a disparity between biological properties of flavonoids observed in vitro and their bioactivity in vivo [244-246]. Similarly, while many of the naturally occurring flavonoids have the potential to be effective anti-cancer agents in vitro such beneficial effects cannot be achieved in humans primarily owing to the low bioavailability of many of these plant-derived secondary metabolites in the body [244-246]. Hence the bioavailability of anti-cancer flavonoids must be investigated in detail. To explain the bioactivity of a flavonoid compound (the compound must enter the circulation and reach the tissues, in its native or metabolized form, in a sufficient quantity to exert biological activity) it is critical to understand the process of its absorption, bioavailability and its metabolism [244]. In the body glycosylated flavonoids such as flavonols, isoflavones, flavones and anthocyanins are generally hydrolyzed into their respective aglycones by intestinal or colon microflora prior to absorption $[55,244,247]$. The lipophilic aglycones enter the intestinal epithelial cells via passive diffusion while the epithelial transporters support the uptake of glycosides into the intestinal epithelial cells [247]. The rate of absorption of glycosylated flavonoids are much lesser when compared to than aglycone flavonoids in the intestine $[245,248]$. After absorption, flavonoids are subject to metabolic modifications primarily in the small intestine, liver and kidney [244,247]. The post-absorptive metabolic changes such as methylation, sulfation, or glucuronidation of the flavonoids before entering circulation and target tissues could also vastly alter their biological properties [55]. Additionally, the ingested flavonoid compounds, that remain unabsorbed in the proximal intestine, reach the colon where they are exposed to the colonic microbes which degrade these flavonoid molecules during which the heterocyclic oxygen containing ring is split and the subsequent degradation products (usually hydroxylated phenyl carboxylic acids) can then be absorbed [244]. Gallic acid and isoflavones, flavanones, catechin and quercetin glucosides are known to have the highest bioavailability while anthocyanins and pro-anthocyanidins have the lowest [246].

In precision medicine major progress in understanding the bioavailability of several flavonoids has been made, but practical solutions to overcome the poor oral bioavailabilities of many of the flavonoid compounds are still lacking [249]. Increasing bioavailability can be achieved by overstepping the barriers of solubility, cellular permeability, metabolic alteration and excretion of these compounds from the human body and facilitating target tissue uptake [249]. Several research groups are attempting to enhance the bioavailability of protective flavonoid compounds by improving intestinal absorption, altering the site of absorption and improving metabolic stability [250]. Although some of the flavonoid compounds are now commercially available in the form of pills, one must exercise caution because the use of large amounts of concentrated flavonoids may pose public health concerns owing to the limited information available on the adverse side effects and drug interactions of these compounds in an in vivo experimental setting and in clinical trials [249]. Although debatable, studies reported that genistein, a soy isoflavone, stimulates the growth and proliferation of MCF-7 breast cancer cells by enhancing the insulin-like growth factor pathway even in the absence of hormones estrogen or progesterone [249,251,252].

There are several different biomolecules (carbohydrates and proteins) in the biological system that have the potential to affect the bioavailability flavonoids [247]. Factors such as age, sex and genotype, in varying degrees can modulate the expression of bioactivity of these biomolecules which in turn influence the absorption, metabolism, circulating concentrations, tissue exposure and elimination of the ingested flavonoid compounds [247]. Therefore, it remains an even bigger challenge to factor-in considerations on age, sex, ongoing disease condition/s, current medications, habitual diet (and physiochemical properties of the food) and nature of the gut microbiome to understand the bioavailability and efficacy of flavonoid compounds as anti-cancer drugs in clinical trials [247]. In order to achieve the effective therapeutic doses used in preclinical studies importance must be given to improved and targeted drug delivery techniques so as to achieve maximum efficiency with minimal adverse side effects. Advances in nanotechnology-based drug delivery systems opens up 
better opportunities for increasing solubility, improving bioavailability and enhancing the targeting capabilities of flavonoids [253]. Current research should focus on designing suitable molecular carriers for the flavonoid drugs to target tissues. Studies using nanoparticle (liposomes, poly-ethylene glycol liposomes, nickel-based, lecithin-based and nanoribbon) carriers for quercetin were reported to be successful in terms of drug delivery into solid tumors in in in vitro and in vivo models of cancers of the central nervous system, lungs, colon, liver and breasts [253-259].

\subsection{Combination Therapy}

Plant extracts have been proven to be strong candidates in the treatment of various types of cancer via modulating apoptotic pathway. The major mechanism involves the activation of apoptotic proteins intrinsically and extrinsically, elevation of ROS, and induction of DNA damage. Additionally, flavonoid-polyphenol/flavonoid and flavonoid-classical anticancer drug combinations reportedly have shown improved efficacy in the treatment of cancer.

A combination of pterostilbene and quercetin effectively reduced cell growth and proliferation, decreased Bcl-2 expression and increased cell death while decreasing the metastatic potential of B16M-F10 melanoma cells in vitro and decreased tumor growth, and improved survival rates in an in vivo mice model bearing B16M-F10 melanoma cells [260]. Genistein and resveratrol in combination reportedly decreased tumor growth and IGF-1 expression in SV40 rats bearing prostate cancer xenografts [261]. Genistein and thearubigin in combination showed synergistic effects and significantly reduced cell proliferation and caused $\mathrm{G}_{2} / \mathrm{M}$ phase cell cycle arrest in PC-3 prostate cancer cells [262]. A combination therapeutic approach using quercetin and EGCG decreased cell proliferation, induced cell death and caused $\mathrm{G}_{2} / \mathrm{M}$ phase cell cycle arrest in PC-3 and LNCaP prostate cancer cells [67]. In this combination of quercetin and EGCG, quercetin improved the bioavailability of the green tea polyphenol and decreased its post-absorptive methylation both in vitro and in vivo [263]. In SCID mice bearing LAPC-4 prostate cancer cell xenografts the combination treatment using quercetin and EGCG was associated with a significant inhibition of tumor cell proliferation, decrease in androgen receptor expression, suppression of the PI3K/Akt signaling pathway and stimulation of apoptosis via increase in the Bax/Bcl-2 ratio [264]. In another study luteolin and EGCG in combination reportedly at low doses (at which single agents induces minimal apoptosis) had synergistic effects and increased apoptosis in in both head and neck and lung cancer cell lines [265]. The same study reported that the combination of luteolin and EGCG decreased tumor growth, inhibited Ki67 expression, increased cell death and reduced tumor growth in in vivo athymic mice models bearing xenografts of head and neck squamous cancer and lung cancer cells [265]. The synergistic effects of the combination of luteolin and EGCG was attributed to increased phosphorylation of p53 and p53 dependent effects on cleavage of PARP and caspase-3 [265]. In MDA-MB-231 triple negative breast cancer cells, a combination of curcumin and EGCG decreased cell proliferation, growth, and viability and caused $\mathrm{G}_{2} / \mathrm{M}$ cell cycle arrest while decreasing tumor volume in athymic nude mice implanted with MDA-MB-231 cells which correlated to the decreased in the levels of VEGF receptor-1 (VEGFR1) [266]. Ellagic acid, a naturally occurring antioxidant occurring in walnuts, cranberries and strawberries potentiated the effects of quercetin on p21waf1/cip1, p53, and MAP-kinases in vitro [267]. Combinations of ellagic acid and quercetin and quercetin and resveratrol decreased cell proliferation, increased cell death via the increase in caspase-3 activity and caused cell cycle arrest in MOLT-4 leukemia cells [268,269].

Suganuma et al., reported that EGCG in combination with tamoxifen or sulindac decreased the release of TNF $\alpha$ and decreased cell proliferation in PC-9 lung cancer cells and that EGCG stimulated the effects of celecoxib and decreased cell proliferation, increased the levels of GADD153 and phosphorylation of p38 in PC-9 and A549 lung cancer cells [270,271]. In another study, a combination of EGCG and celecoxib reportedly decreased cell proliferation, growth and viability of LNCaP, PC-3 and CWR22Rv1 prostate cancer cells and decreased tumor growth, increased the Bax/BCl-2 ratio, PARP cleavage and the expression of caspases-3 and -9 while decreasing the NF- $\mathrm{KB}$ activity and serum levels of PSA and IGF-1 [272]. Combinations of EGCG with other anti-cancer drugs such 
as paclitaxel/docetaxel, doxorubicin, cisplatin, gemcitabine and tasocitinib effectively reduced cell proliferation, increased cell death, reduced tumor growth and improved survival rates in in vitro and in vivo models of cancers of the prostate, breasts, ovaries, liver and pancreas [273-278]. Quercetin in combination with doxorubicin markedly reduced cell proliferation, DNA and protein synthesis and cell invasiveness in MCF-7 and MDA-MB-231 breast cancer cells [279]. In HeP2 laryngeal cancer cells, a combination of quercetin and cisplatin decreased cancer cell proliferation and induced cell death/apoptosis which was mechanistically attributed to the decrease in the phosphorylation of Akt, in the levels of Bcl-xL and Ki67 and the activity of HSP70 while increasing the phosphorylation of JNK, c-fos expression, the Bax/Bcl-2 ratio, ROS production, activity of caspases- 8 and -9 and release of cytochrome c [280]. Combinations of genistein with other anti-cancer drugs such as cisplatin and gemcitabine, effectively reduced cell proliferation, increased cell death and reduced tumor growth in different in vitro and in vivo models of pancreatic cancers [281-283]. Isoflavone treatment in PC-3 prostate cancer cells increased the susceptibility of these cells to radiotherapy both in vitro and in vivo, reduced tumor growth and metastasis to para-aortic lymph nodes while increasing the expression of Bax and PARP cleavage and decreasing the levels of Bcl-xL and survivin [284-286].

Ongoing and completed clinical trials have reported the safety and efficacy of polyphenols as anticancer agents [55,287-289]. Clinical trials are also currently testing the flavonoid-flavonoid/ polyphenol and flavonoid-anticancer drug combinations due to the promising pre-clinical data available on the use of such combinations [55]. A phase I study showed the efficacy, safety and tolerability of muscadine grape skin extract (which contains ellagic acid, quercetin, and resveratrol) in men with biochemically recurrent prostate cancer [290]. In breast cancer patients receiving radiotherapy administration of encapsulated EGCG ( $400 \mathrm{mg}$, thrice a day, orally) reduced the levels of VEGF and HGF in the serum and suppressed the activation of MMP-2 and MMP-9 and inhibited factors associated with the progression and metastasis of breast cancer [291]. Additionally, the exposure of MDA-MB-231 cells to the serum of breast cancer patients who received a combination of EGCG and radiotherapy evidently suppressed MDA-MB-231 cell viability, caused $G_{0} / G_{1}$ cell cycle arrest and induced cell death by apoptosis [291].

Details of completed and ongoing clinical trials using quercetin, genistein, EGCG and various other flavonoids in the treatment of different cancers can be found at https:/ / clinicaltrials.gov.

The use of drug combinations over single drug applications should prove beneficial in (1) decreasing the dosage/concentration of the drug being used, (2) improving bioavailability, (3) overcoming the resistance that can acquired against a drug, (4) sensitizing the chemotherapy/ radiotherapy resistant cancers to treatment, (5) reducing cancer cell metastasis and invasion, (6) reducing chances of relapse and (7) improving overall efficacy of cancer treatment. Additional studies are warranted in order to examine the bioavailability, efficacy, safety, tolerance and drug delivery options for flavonoids to be used in the treatment of cancers.

Author Contributions: The authors contributed as follows: Conceptualization, M.A. and D.B.; Literature Review and Resources, M.A.; P.K.; and A.L.; Writing-Original Draft Preparation, M.A.; Writing-Review and Editing, S.M.S.; E.V.; S.V.; P.K.; A.L. and D.B.; Figure Preparation and Editing, M.A.; Visualization, M.A.; S.M.S. and D.B.; Supervision, D.B.; Project Administration, D.B.; Funding Acquisition, D.B. All authors reviewed the results and approved the final version of the manuscript.

Funding: The research was supported by the Bridge Funding Grant (Nov. 2017-current) awarded to Dietrich Büsselberg by the BMRP program at Weill Cornell Medicine-Qatar, a program funded by Qatar Foundation, Doha, Qatar.

Acknowledgments: We thank Steven Stay (Weill Cornell Medicine-Qatar) for the linguistic and grammatical corrections/suggestions.

Conflicts of Interest: The authors declare no conflict of interest. The funders had no role in the design of the study; in the collection, analyses, or interpretation of data; in the writing of the manuscript, or in the decision to publish the results. 


\section{Abbreviations}

\begin{tabular}{|c|c|}
\hline$\Delta \Psi \mathrm{m}$ & Mitochondrial Membrane Potential \\
\hline 5-FU & 5-Fluorouracil \\
\hline AIF & Apoptosis Inducing Factor \\
\hline Akt & Protein Kinase B \\
\hline AMPK & Adenosine Monophosphate-Activated Protein Kinase \\
\hline APAF-1 & Apoptosis Protease Activating Factor 1 \\
\hline Bad & Bcl-2 Associated Death Promoter \\
\hline Bak & Bcl-2 Antagonist and Killer \\
\hline Bax & Bcl-2 Associated X Protein \\
\hline Bcl-2 & B Cell Lymphoma 2 Proteins \\
\hline Bcl-xL & B Cell Lymphoma-Extra Large \\
\hline BH3 & Bcl-2 Homology 3 \\
\hline Bim & Bcl-2-Like Protein 11 \\
\hline BIR & Baculoviral IAP Repeat Domains \\
\hline CAT & Catalase \\
\hline c-Flip & Caspase FLICE-Like Inhibitory Protein \\
\hline $\mathrm{CHOP}$ & C/EBP Homologous Protein \\
\hline c-IAP & Cellular Inhibitor of Apoptosis Protein \\
\hline Cox-2 & Cyclooxygenase 2 \\
\hline DISC & Death-Inducing Signaling Complex \\
\hline DR & Death Receptor \\
\hline EGCG & Epigallocatechin Gallate \\
\hline EndoG & Endonuclease G \\
\hline ER & Endoplasmic Reticulum \\
\hline ESC & Esophageal Squamous Carcinoma \\
\hline FADD & Fas-Associated Protein with Death \\
\hline FasL & Fas Ligand \\
\hline GPx & Glutathione Peroxidase \\
\hline GRP & Glucose Related Protein \\
\hline GSH & Glutathione \\
\hline $\mathrm{HCC}$ & Hepatocellular Carcinoma \\
\hline HGF & Hepatocyte Growth Factor \\
\hline Her2 & Human Epidermal Growth Factor \\
\hline HSP & Heat Shock Protein \\
\hline MAPK & Mitogen-Activated Protein Kinase \\
\hline Mcl-1 & Myeloid Cell Leukemia 1 \\
\hline MDR & Multi Drug Resistance \\
\hline MMP & Matrix Metalloproteinase \\
\hline MOMP & Mitochondrial Outer Membrane Permeabilization \\
\hline mTOR & Mammalian Target of Rapamycin \\
\hline NAC & N Acetyl Cysteine \\
\hline NF-кB & Nuclear Factor Kappa Beta Pathway \\
\hline N-IAP & Neuronal Apoptosis Inhibitory Protein \\
\hline NSLC & Non-Small Lung Carcinoma \\
\hline Omi/HtrA2 & Temperature Requirement Protein A2 \\
\hline PARP & Poly (ADP-Ribose) Polymerase \\
\hline PI3K & Phosphatidylinositol 3-Kinase \\
\hline PUMA & P53-Upregulated Modulator of Apoptosis \\
\hline RCC & Renal Cell Carcinoma \\
\hline ROS & Reactive Oxygen Species \\
\hline Smac/DIABLO & $\begin{array}{l}\text { Second Mitochondrial Derived Activator of Caspase/Direct Inhibitor of } \\
\text { Apoptosis-Binding with A Low Isoelectric Point }\end{array}$ \\
\hline
\end{tabular}




$\begin{array}{ll}\text { SOD } & \text { Super Oxide Dismutase } \\ \text { t-Bid } & \text { Truncated-Bid } \\ \text { TNF } & \text { Tumor Necrosis Factor } \\ \text { TRADD } & \text { TNF-Related Apoptosis-Inducing Ligand } \\ \text { TRIAL } & \text { TNFRSF1A-Associated Via Death Domain } \\ \text { uPA } & \text { Urokinase Plasminogen } \\ \text { VDAC } & \text { Voltage Dependent Anion Channel } \\ \text { VEGF } & \text { Vascular Endothelial Growth Factor } \\ \text { x-IAP } & \text { X-Linked Inhibitor of Apoptosis }\end{array}$

\section{References}

1. Igney, F.H.; Krammer, P.H. Death and anti-death: Tumour resistance to apoptosis. Nat. Rev. 2002, 2, $277-288$. [CrossRef] [PubMed]

2. Safarzadeh, E.; Shotorbani, S.S.; Baradaran, B. Herbal medicine as inducers of apoptosis in cancer treatment. Adv. Pharm. Bull. 2014, 4, 421-427. [PubMed]

3. Prakash, O.; Kumar, A.; Kumar, P. Anticancer potential of plants and natural products: A review. Am. J. Pharmacol. Sci. 2013, 1, 104-115. [CrossRef]

4. Hanahan, D.; Weinberg, R.A. Review hallmarks of cancer: The next generation. Cell 2011, 144, 646-674. [CrossRef] [PubMed]

5. Hanahan, D.; Weinberg, R.A.; Francisco, S. The hallmarks of cancer review university of california at san francisco. Cell 2000, 100, 57-70. [CrossRef]

6. Fan, T.J.; Han, L.H.; Cong, R.S.; Liang, J. Caspase family proteases and apoptosis. Acta Biochim. Biophys. Sin. 2005, 37, 719-727. [CrossRef]

7. Indran, I.R.; Tufo, G.; Pervaiz, S.; Brenner, C. Recent advances in apoptosis, mitochondria and drug resistance in cancer cells. Biochim. Biophys. Acta Bioenerget. 2011, 1807, 735-745. [CrossRef]

8. Wong, R.S.Y. Apoptosis in cancer: From pathogenesis to treatment. J. Exp. Clin. Cancer Res. 2011, $30,87$. [CrossRef]

9. Kasibhatla, S.; Tseng, B. Why target apoptosis in cancer treatment? Mol. Cancer Ther. 2003, 2, 573-580.

10. Opferman, J.T.; Kothari, A. Anti-apoptotic bcl-2 family members in development. Cell Death Differ. 2018, 25, 37-45. [CrossRef]

11. Aubrey, B.J.; Kelly, G.L.; Janic, A.; Herold, M.J.; Strasser, A. How does p53 induce apoptosis and how does this relate to p53-mediated tumour suppression? Cell Death Differ. 2018, 25, 104-113. [CrossRef] [PubMed]

12. Zhao, Y.; Coloff, J.L.; Ferguson, E.C.; Jacobs, S.R.; Cui, K.; Rathmell, J.C. Glucose metabolism attenuates p53 and puma-dependent cell death upon growth factor deprivation. J. Biol. Chem. 2008, 283, 36344-36353. [CrossRef] [PubMed]

13. Rathore, R.; McCallum, J.E.; Varghese, E.; Maria, A.; Büsselberg, D. Overcoming chemotherapy drug resistance by targeting inhibitors of apoptosis proteins (iaps). Apoptosis 2017, 22, 898-919. [CrossRef] [PubMed]

14. Lopez, J.; Tait, S.W.G. Mitochondrial apoptosis: Killing cancer using the enemy within. Br. J. Cancer 2015, 112, 957-962. [CrossRef] [PubMed]

15. Chwieralski, C.E.; Welte, T.; Bühling, F. Cathepsin-regulated apoptosis. Apoptosis 2006, 11, $143-149$. [CrossRef] [PubMed]

16. Manzl, C.; Krumschnabel, G.; Bock, F.; Sohm, B.; Labi, V.; Baumgartner, F.; Logette, E.; Tschopp, J.; Villunger, A. Caspase-2 activation in the absence of piddosome formation. J. Cell Biol. 2009, 185, 291-303. [CrossRef]

17. Boehning, D.; Patterson, R.L.; Sedaghat, L.; Glebova, N.O.; Kurosaki, T.; Snyder, S.H.; Insp, R. Cytochrome c binds to inositol $(1,4,5)$ trisphosphate receptors, amplifying calcium-dependent apoptosis. Nat. Cell Biol. 2003, 5, 1051. [CrossRef]

18. Momeni, H.R.; Ph, D. Role of calpain in apoptosis. Cell J. 2011, 13, 65-72.

19. Stewart, T.A.; Yapa, K.T.D.S.; Monteith, G.R. Altered calcium signaling in cancer cells. Biochim. Biophys. Acta 2015, 1848, 2502-2511. [CrossRef]

20. Panche, A.D.; Diwan, A.D.; Chandra, S.R. Flavonoids: An overview. J. Nutr. Sci. 2016, 5, 1-15. [CrossRef] 
21. Varghese, E.; Samuel, S.M.; Abotaleb, M.; Cheema, S.; Mamtani, R.; Busselberg, D. The "yin and yang" of natural compounds in anticancer therapy of triple-negative breast cancers. Cancers 2018, 10, 346. [CrossRef]

22. Liu, R.H. Nutrition, and cancer potential synergy of phytochemicals in cancer prevention: Mechanism of action 1. Int. Res. Conf. Food Nutr. Cancer Potential 2004, 134, 3479-3485.

23. Batra, P.; Sharma, A.K. Anti-cancer potential of flavonoids: Recent trends and future perspectives. Biotech 2013, 3, 439-459. [CrossRef] [PubMed]

24. Tapas, A.R.; Sakarkar, D.M.; Kakde, R.B. Flavonoids as nutraceuticals: A review. Trop. J. Pharm. Res. 2008, 7, 1089-1099. [CrossRef]

25. Ravishankar, D.; Rajora, A.K.; Greco, F.; Osborn, H.M.I. Flavonoids as prospective compounds for anti-cancer therapy. Int. J. Biochem. Cell Biol. 2013, 45, 2821-2831. [CrossRef]

26. Kelly, G.S. Quercetin. Altern. Med. Rev. 2011, 16, 172-194. [PubMed]

27. Iqbal, J.; Abbasi, B.A.; Mahmood, T.; Kanwal, S.; Ali, B.; Shah, S.A. Plant-derived anticancer agents: A green anticancer approach. Asian Pac. J. Trop. Biomed. 2017, 7, 1129-1150. [CrossRef]

28. Parhiz, H.; Roohbakhsh, A.; Soltani, F.; Rezaee, R.; Iranshahi, M. Antioxidant and anti-inflammatory properties of the citrus flavonoids hesperidin and hesperetin: An updated review of their molecular mechanisms and experimental models. Phytother. Res. 2015, 29, 323-331. [CrossRef]

29. Zhang, J.; Wu, D.; Vikash; Song, J.; Wang, J.; Yi, J.; Dong, W. Hesperetin induces the apoptosis of gastric cancer cells via activating mitochondrial pathway by increasing reactive oxygen species. Dig. Dis. Sci. 2015, 60, 2985-2995. [CrossRef]

30. Wu, D.; Zhang, J.; Wang, J.; Li, J.; Liao, F.; Dong, W. Hesperetin induces apoptosis of esophageal cancer cells via mitochondrial pathway mediated by the increased intracellular reactive oxygen species. Tumor Biol. 2016, 37, 3451-3459. [CrossRef]

31. Palit, S.; Kar, S.; Sharma, G.; Das, P.K. Hesperetin induces apoptosis in breast carcinoma by triggering accumulation of ros and activation of ask1/jnk pathway. J. Cell. Physiol. 2015, 230, 1729-1739. [CrossRef] [PubMed]

32. Sivagami, G.; Vinothkumar, R.; Preethy, C.P.; Riyasdeen, A.; Akbarsha, M.A.; Menon, V.P.; Nalini, N. Role of hesperetin (a natural flavonoid) and its analogue on apoptosis in ht-29 human colon adenocarcinoma cell line-A comparative study. Food Chem. Toxicol. 2012, 50, 660-671. [CrossRef] [PubMed]

33. Elango, R.; Athinarayanan, J.; Subbarayan, V.P.; Lei, D.K.Y.; Alshatwi, A.A. Hesperetin induces an apoptosis-triggered extrinsic pathway and a p53- independent pathway in human lung cancer h522 cells. J. Asian Nat. Prod. Res. 2017, 6020, 1-11. [CrossRef] [PubMed]

34. Alshatwi, A.A.; Ramesh, E.; Periasamy, V.S.; Subash-Babu, P. The apoptotic effect of hesperetin on human cervical cancer cells is mediated through cell cycle arrest, death receptor, and mitochondrial pathways. Fund. Clin. Pharmacol. 2013, 27, 581-592. [CrossRef] [PubMed]

35. Sambantham, S.; Radha, M.; Paramasivam, A.; Anandan, B.; Malathi, R.; Chandra, S.R.; Jayaraman, G. Molecular mechanism underlying hesperetin-induced apoptosis by in silico analysis and in prostate cancer pc-3 cells. Asian Pac. J. Cancer Prev. 2013, 14, 4347-4352. [CrossRef]

36. Patel, K.; Singh, G.K.; Patel, D.K. A review on pharmacological and analytical aspects of naringenin. Chin. J. Integr. Med. 2014, 24, 551-560. [CrossRef]

37. Bao, L.; Liu, F.; Guo, H.B.; Li, Y.; Tan, B.B.; Zhang, W.X.; Peng, Y.H. Naringenin inhibits proliferation, migration, and invasion as well as induces apoptosis of gastric cancer sgc7901 cell line by downregulation of akt pathway. Tumor Biol. 2016, 37, 11365-11374. [CrossRef]

38. Zhang, H.; Zhong, X.; Zhang, X.; Shang, D.; Zhou, Y.; Zhang, C. Enhanced anticancer effect of abt-737 in combination with naringenin on gastric cancer cells. Exp. Ther. Med. 2016, 11, 669-673. [CrossRef]

39. Ahamad, M.S.; Siddiqui, S.; Jafri, A.; Ahmad, S.; Afzal, M.; Arshad, M. Induction of apoptosis and antiproliferative activity of naringenin in human epidermoid carcinoma cell through ros generation and cell cycle arrest. PLoS ONE 2014, 9, e110003. [CrossRef]

40. Arul, D.; Subramanian, P. Naringenin (citrus flavonone) induces growth inhibition, cell cycle arrest and apoptosis in human hepatocellular carcinoma cells. Pathol. Oncol. Res. 2013, 19, 763-770. [CrossRef]

41. Kapoor, R.; Rizvi, F.; Kakkar, P. Naringenin prevents high glucose-induced mitochondria-mediated apoptosis involving aif, endo-g and caspases. Apoptosis 2013, 18, 9-27. [CrossRef] [PubMed] 
42. Bulzomi, P.; Bolli, A.; Galluzzo, P.; Acconcia, F.; Ascenzi, P.; Marino, M. The naringenin-induced proapoptotic effect in breast cancer cell lines holds out against a high bisphenol a background. IUBMB Life 2012, 64, 690-696. [CrossRef] [PubMed]

43. Krishnakumar, N.; Sulfikkarali, N.; RajendraPrasad, N.; Karthikeyan, S. Enhanced anticancer activity of naringenin-loaded nanoparticles in human cervical (hela) cancer cells. Biomed. Prev. Nutr. 2011, 1, 223-231. [CrossRef]

44. Kim, J.H.; Kang, J.W.; Kim, M.S.; Bak, Y.; Park, Y.S.; Jung, K.Y.; Lim, Y.H.; Yoon, D.Y. The apoptotic effects of the flavonoid n101-2 in human cervical cancer cells. Toxicol. In Vitro 2012, 26, 67-73. [CrossRef] [PubMed]

45. Park, H.J.; Choi, Y.J.; Lee, J.H.; Nam, M.J. Naringenin causes ask1-induced apoptosis via reactive oxygen species in human pancreatic cancer cells. Food Chem. Toxicol. 2017, 99, 1-8. [CrossRef] [PubMed]

46. Abdulkhaleq, L.A.; Assi, M.A.; Noor, M.H.M.; Abdullah, R.; Saad, M.Z.; Taufiq-Yap, Y.H. Therapeutic uses of epicatechin in diabetes and cancer. Vet. World 2017, 10, 869-872. [CrossRef]

47. Shay, J.; Elbaz, H.A.; Lee, I.; Zielske, S.P.; Malek, M.H. Molecular mechanisms and therapeutic effects of (-) -epicatechin and other polyphenols in cancer, inflammation, diabetes, andneurodegeneration. Oxid. Med. Cell. Longev. 2015, 2015, 181260. [CrossRef]

48. Amin, A.; Gali-muhtasib, H.; Ocker, M.; Schneider-stock, R. Overview of major classes of plant-derived anticancer drugs. Int. J. Biomed. Sci. 2009, 5, 1-11.

49. Moradzadeh, M.; Hosseini, A.; Erfanian, S.; Rezaei, H. Epigallocatechin-3-gallate promotes apoptosis in human breast cancer $447 \mathrm{~d}$ cells through down-regulation of pi3k/akt and telomerase. Pharmacol. Rep. 2017, 69, 924-928. [CrossRef]

50. Li, M.-J. Green tea compounds in breast cancer prevention and treatment. World J. Clin. Oncol. 2014, 5, 520. [CrossRef]

51. Liu, L.; Hou, L.; Gu, S.; Zuo, X.; Meng, D.; Luo, M.; Zhang, X.; Huang, S.; Zhao, X. Molecular mechanism of epigallocatechin-3-gallate in human esophageal squamous cell carcinoma in vitro and in vivo. Oncol. Rep. 2015, 33, 297-303. [CrossRef]

52. Cerezo-Guisado, M.I.; Zur, R.; Lorenzo, M.J.; Risco, A.; Martín-Serrano, M.A.; Alvarez-Barrientos, A.; Cuenda, A.; Centeno, F. Implication of akt, erk1/2 and alternative p38mapk signalling pathways in human colon cancer cell apoptosis induced by green tea egcg. Food Chem. Toxicol. 2015, 84, 125-132. [CrossRef]

53. Kwak, T.W.; Park, S.B.; Kim, H.J.; Jeong, Y.I.L.; Kang, D.H. Anticancer activities of epigallocatechin-3-gallate against cholangiocarcinoma cells. OncoTargets Ther. 2017, 10, 137-144. [CrossRef]

54. Sonoda, J.I.; Ikeda, R.; Baba, Y.; Narumi, K.; Kawachi, A.; Tomishige, E.; Nishihara, K.; Takeda, Y.; Yamada, K.; Sato, K.; et al. Green tea catechin, epigallocatechin-3-gallate, attenuates the cell viability of human non-small-cell lung cancer a549 cells via reducing bcl-xl expression. Exp. Ther. Med. 2014, 8, 59-63. [CrossRef]

55. Fantini, M.; Benvenuto, M.; Masuelli, L.; Frajese, G.V.; Tresoldi, I.; Modesti, A.; Bei, R. In vitro and in vivo antitumoral effects of combinations of polyphenols, or polyphenols and anticancer drugs: Perspectives on cancer treatment. Int. J. Mol. Sci. 2015, 16, 9236-9282. [CrossRef]

56. Gupta, S.; Hastak, K.; Afaq, F.; Ahmad, N.; Mukhtar, H. Essential role of caspases in epigallocatechin3-gallate-mediated inhibition of nuclear factor kappa b and induction of apoptosis. Oncogene 2004, 23, 2507-2522. [CrossRef]

57. Pan, M.H.; Lin, C.C.; Lin, J.K.; Chen, W.J. Tea polyphenol (-)-epigallocatechin 3-gallate suppresses heregulin-beta1-induced fatty acid synthase expression in human breast cancer cells by inhibiting phosphatidylinositol 3-kinase/akt and mitogen-activated protein kinase cascade signaling. J. Agric. Food Chem. 2007, 55, 5030-5037. [CrossRef]

58. Pianetti, S.; Guo, S.; Kavanagh, K.T.; Sonenshein, G.E. Green tea polyphenol epigallocatechin-3 gallate inhibits her-2/neu signaling, proliferation, and transformed phenotype of breast cancer cells. Cancer Res. 2002, 62, 652-655.

59. Masuda, M.; Suzui, M.; Lim, J.T.; Deguchi, A.; Soh, J.W.; Weinstein, I.B. Epigallocatechin-3-gallate decreases vegf production in head and neck and breast carcinoma cells by inhibiting egfr-related pathways of signal transduction. J. Exp. Ther. Oncol. 2002, 2, 350-359. [CrossRef]

60. Ranganathan, S.; Halagowder, D. Quercetin suppresses twist to induce apoptosis in mcf-7 breast cancer cells. PLoS ONE 2015, 10, e0141370. [CrossRef] 
61. Damnjanovic, I.; Najman, S.; Stojanovic, S.; Stojanovic, D.; Veljkovic, A.; Kocic, H.; Langerholc, T.; Damnjanovic, Z.; Pesic, S. Quercetin induces apoptosis and necroptosis in mcf-7 breast cancer cells. Bratislavské Lekárske Listy 2017, 116, 227-232.

62. Zhang, L. Quercetin inhibits human breast cancer cell proliferation and induces apoptosis via bcl-2 and bax regulation. Mol. Med. Rep. 2012, 1453-1456. [CrossRef]

63. Chou, C.-C.; Yang, J.-S.; Lu, H.-F.; Ip, S.-W.; Lo, C.; Wu, C.-C.; Lin, J.-P.; Tang, N.-Y.; Chung, J.-G.; Chou, M.-J.; et al. Quercetin-mediated cell cycle arrest and apoptosis involving activation of a caspase cascade through the mitochondrial pathway in human breast cancer mcf-7 cells. Arch. Pharm. Res. 2010, 33, 1181-1191. [CrossRef]

64. Seo, H.S.; Ku, J.M.; Choi, H.S.; Choi, Y.K.; Woo, J.K.; Kim, M.; Kim, I.; Na, C.H.; Hur, H.; Jang, B.H.; et al. Quercetin induces caspase-dependent extrinsic apoptosis through inhibition of signal transducer and activator of transcription 3 signaling in her2-overexpressing bt- 474 breast cancer cells. Oncol. Rep. 2016, 36, 31-42. [CrossRef]

65. Niu, G.; Yin, S.; Xie, S.; Li, Y.; Nie, D.; Ma, L.; Wang, X.; Wu, Y. Quercetin induces apoptosis by activating caspase-3 and regulating bcl-2 and cyclooxygenase-2 pathways in human hl-60 cells. Acta Biochim. Biophys. Sin. 2011, 43, 30-37. [CrossRef]

66. Granato, M.; Rizzello, C.; Montani, M.S.G.; Cuomo, L.; Vitillo, M.; Santarelli, R.; Gonnella, R.; D’Orazi, G.; Faggioni, A.; Cirone, M. Quercetin induces apoptosis and autophagy in primary effusion lymphoma cells by inhibiting pi3k/akt/mtor and stat3 signaling pathways. J. Nutr. Biochem. 2017, 41, 124-136. [CrossRef]

67. Wang, P.; Heber, D.; Henning, S.M. Quercetin increased the antiproliferative activity of green tea polyphenol (-)-epigallocatechin gallate in prostate cancer cells. Nutr. Cancer 2012, 64, 580-587. [CrossRef]

68. Sun, S.; Gong, F.; Liu, P.; Miao, Q. Metformin combined with quercetin synergistically repressed prostate cancer cells via inhibition of vegf/pi3k/akt signaling pathway. Gene 2018, 664, 50-57. [CrossRef]

69. Jeong, J.H.; An, J.Y.; Kwon, Y.T.; Li, L.Y.; Lee, Y.J. Quercetin-induced ubiquitination and down-regulation of her-2/neu. J. Cell. Biochem. 2008, 105, 585-595. [CrossRef]

70. Granado-Serrano, A.B.; Martin, M.A.; Bravo, L.; Goya, L.; Ramos, S. Quercetin modulates nf-kappa b and ap-1/jnk pathways to induce cell death in human hepatoma cells. Nutr. Cancer 2010, 62, 390-401. [CrossRef]

71. Calder, M.; Burgos, E. A review on the dietary flavonoid kaempferol. Mini Rev. Med. Chem. 2011, 11, $298-344$.

72. Chen, A.Y.; Chen, Y.C. A review of the dietary flavonoid, kaempferol on human health and cancer chemoprevention. Food Chem. 2013, 138, 2099-2107. [CrossRef]

73. Kim, S.H.; Choi, K.C. Anti-cancer effect and underlying mechanism(s) of kaempferol, a phytoestrogen, on the regulation of apoptosis in diverse cancer cell models. Toxicol. Res. 2013, 29, 229-234. [CrossRef]

74. Luo, H.; Jiang, B.; Li, B.; Li, Z.; Jiang, B.H.; Chen, Y.C. Kaempferol nanoparticles achieve strong and selective inhibition of ovarian cancer cell viability. Int. J. Nanomed. 2012, 7, 3951-3959.

75. Li, W.; Du, B.; Wang, T.; Wang, S.; Zhang, J. Kaempferol induces apoptosis in human hct116 colon cancer cells via the ataxia-telangiectasia mutated-p53 pathway with the involvement of p53 upregulated modulator of apoptosis. Chem.-Biol. Interact. 2009, 177, 121-127. [CrossRef]

76. Luo, H.; Rankin, G.O.; Li, Z.; DePriest, L.; Chen, Y.C. Kaempferol induces apoptosis in ovarian cancer cells through activating p53 in the intrinsic pathway. Food Chem. 2011, 128, 513-519.

77. Moradzadeh, M.; Tabarraei, A.; Sadeghnia, H.R.; Ghorbani, A.; Mohamadkhani, A.; Erfanian, S.; Sahebkar, A. Kaempferol increases apoptosis in human acute promyelocytic leukemia cells and inhibits multidrug resistance genes. J. Cell. Biochem. 2018, 119, 2288-2297. [CrossRef]

78. Luo, H.; Daddysman, M.K.; Rankin, G.O.; Jiang, B.H.; Chen, Y.C. Kaempferol enhances cisplatin's effect on ovarian cancer cells through promoting apoptosis caused by down regulation of cmyc. Cancer Cell Int. 2010, 10, 1-9. [CrossRef]

79. Guo, H.; Ren, F.; Zhang, L.I.; Zhang, X.; Yang, R. Kaempferol induces apoptosis in hepg2 cells via activation of the endoplasmic reticulum stress pathway. Mol. Med. Rep. 2016, 13, 2791-2800. [CrossRef]

80. Jeong, J.C.; Kim, M.S.; Kim, T.H.; Kim, Y.K. Kaempferol induces cell death through erk and akt-dependent down-regulation of xiap and survivin in human glioma cells. Neurochem. Res. 2009, 34, 991-1001. [CrossRef]

81. Kashafi, E.; Moradzadeh, M.; Mohamadkhani, A.; Erfanian, S. Kaempferol increases apoptosis in human cervical cancer hela cells via pi3k/akt and telomerase pathways. Biomed. Pharmacother. 2017, 89, 573-577. [CrossRef] [PubMed] 
82. Khan, N.; Syed, D.N.; Ahmad, N.; Mukhtar, H. Fisetin: A dietary antioxidant for health promotion. Antioxid. Redox Signal. 2013, 19, 151-162. [CrossRef] [PubMed]

83. Khan, N.; Afaq, F.; Syed, D.N. Fisetin, a novel dietary flavonoid, causes apoptosis and cell cycle arrest in human prostate cancer Incap cells. Carcinogenesis 2018, 29, 1049-1056. [CrossRef] [PubMed]

84. Szliszka, E.; Helewski, K.J.; Mizgala, E.; Krol, W. The dietary flavonol fisetin enhances the apoptosis-inducing potential of trail in prostate cancer cells. Int. J. Oncol. 2011, 39, 771-779. [PubMed]

85. Sabarwal, A.; Agarwal, R.; Singh, R.P. Fisetin inhibits cellular proliferation and induces mitochondria-dependent apoptosis in human gastric cancer cells. Mol. Carcinogen. 2017, 514, 499-514. [CrossRef]

86. Lin, M.-T.; Lin, C.-L.; Lin, T.-Y.; Cheng, C.-W.; Yang, S.-F.; Lin, C.-L.; Wu, C.-C.; Hsieh, Y.-H.; Tsai, J.-P. Synergistic effect of fisetin combined with sorafenib in human cervical cancer hela cells through activation of death receptor-5 mediated caspase-8/caspase-3 and the mitochondria-dependent apoptotic pathway. Tumor Biol. 2015, 60, 1396-1405. [CrossRef]

87. Ying, T.H.; Yang, S.F.; Tsai, S.J.; Hsieh, S.C.; Huang, Y.C.; Bau, D.T.; Hsieh, Y.H. Fisetin induces apoptosis in human cervical cancer hela cells through erk1/2-mediated activation of caspase-8-/caspase-3-dependent pathway. Arch Toxicol 2012, 86, 263-273.

88. Kang, K.A.; Piao, M.J.; Ruwan, S.; Madduma, K. Fisetin induces apoptosis and endoplasmic reticulum stress in human non-small cell lung cancer through inhibition of the mapk signaling pathway. Tumor Biol. 2016, 37, 9615-9624. [CrossRef]

89. Yi, C.; Zhang, Y.; Yu, Z.; Xiao, Y.; Wang, J.; Qiu, H.; Yu, W.; Tang, R.; Yuan, Y.; Guo, W.; et al. Melatonin enhances the anti-tumor effect of fisetin by inhibiting cox-2/inos and $\mathrm{nf}-\mathrm{kb} / \mathrm{p} 300$ signaling pathways. PLoS ONE 2014, 9, e99943. [CrossRef]

90. Young, K.; Jeong, S.-J.; Kim, S.-H.; Hoon, J.; Kim, J.-H.; Koh, W.; Chen, C.-Y.; Kim, S.-H. Activation of reactive oxygen species/amp activated protein kinase signaling mediates fisetin-induced apoptosis in multiple myeloma u266 cells. Cancer Lett. 2012, 319, 197-202.

91. Devi, K.P.; Rajavel, T.; Habtemariam, S.; Nabavi, S.F.; Nabavi, S.M. Molecular mechanisms underlying anticancer effects of myricetin. Life Sci. 2015, 142, 19-25. [CrossRef] [PubMed]

92. Kim, M.E.; Ha, T.K.; Yoon, J.H.; Lee, J.S. Myricetin induces cell death of human colon cancer cells. Anticancer Res. 2014, 34, 701-706. [PubMed]

93. Kim, W.; Yang, H.J.; Youn, H.; Yun, Y.J.; Seong, K.M.; Youn, B. Myricetin inhibits akt survival signaling and induces bad-mediated apoptosis in a low dose ultraviolet (uv)-b-irradiated hacat human immortalized keratinocytes. J. Radiat. Res. 2010, 51, 285-296. [CrossRef] [PubMed]

94. Xu, Y.; Xie, Q.; Wu, S.; Yi, D.; Yu, Y.; Liu, S.; Li, S.; Li, Z. Myricetin induces apoptosis via endoplasmic reticulum stress and DNA double-strand breaks in human ovarian cancer cells. Mol. Med. Rep. 2016, 13, 2094-2100. [CrossRef]

95. Huang, H.; Chen, A.Y.; Ye, X.; Li, B.; Rojanasakul, Y.; Rankin, G.O.; Chen, Y.C. Myricetin inhibits proliferation of cisplatin-resistant cancer cells through a p53-dependent apoptotic pathway. Int. J. Oncol. 2015, 47, 1494-1502. [CrossRef] [PubMed]

96. Knickle, A.; Fernando, W.; Greenshields, A.L.; Rupasinghe, H.P.V.; Hoskin, D.W. Myricetin-induced apoptosis of triple-negative breast cancer cells is mediated by the iron-dependent generation of reactive oxygen species from hydrogen peroxide. Food Chem. Toxicol. 2018, 118, 154-167. [CrossRef] [PubMed]

97. Lirdprapamongkol, K.; Sakurai, H.; Abdelhamed, S.; Yokoyama, S.; Athikomkulchai, S.; Viriyaroj, A.; Awale, S.; Ruchirawat, S.; Svasti, J.; Saiki, I. Chrysin overcomes trail resistance of cancer cells through mcl-1 downregulation by inhibiting stat3 phosphorylation. Int. J. Oncol. 2013, 43, 329-337. [CrossRef] [PubMed]

98. Kim, D.A.; Jeon, Y.K.; Nam, M.J. Galangin induces apoptosis in gastric cancer cells via regulation of ubiquitin carboxy-terminal hydrolase isozyme 11 and glutathione s-transferase p. Food Chem. Toxicol. 2012, 50, 684-688. [CrossRef]

99. Zhang, H.-T. Galangin induces apoptosis of hepatocellular carcinoma cells via the mitochondrial pathway. World J. Gastroenterol. 2010, 16, 3377. [CrossRef]

100. Zhang, H.T.; Wu, J.; Wen, M.; Su, L.J.; Luo, H. Galangin induces apoptosis in hepatocellular carcinoma cells through the caspase 8/t-bid mitochondrial pathway. J. Asian Nat. Prod. Res. 2012, 14, 626-633. [CrossRef]

101. Zhang, W.; Lan, Y.; Huang, Q.; Hua, Z. Galangin induces b16f10 melanoma cell apoptosis via mitochondrial pathway and sustained activation of p38 mapk. Cytotechnology 2013, 65, 447-455. [CrossRef] [PubMed] 
102. Ren, K.; Zhang, W.; Wu, G.; Ren, J.; Lu, H.; Li, Z.; Han, X. Synergistic anti-cancer effects of galangin and berberine through apoptosis induction and proliferation inhibition in oesophageal carcinoma cells. Biomed. Pharmacother. 2016, 84, 1748-1759. [CrossRef] [PubMed]

103. Rasul, A.; Zhao, B.J.; Liu, J.; Liu, B.; Sun, J.X.; Li, J.; Li, X.M. Molecular mechanisms of casticin action: An update on its antitumor functions. Asian Pac. J. Cancer Prev. 2014, 15, 9049-9058. [CrossRef] [PubMed]

104. Chan, E.W.C.; Wong, S.K.; Chan, H.T. Casticin from vitex species: A short review on its anticancer and anti-inflammatory properties. J. Integr. Med. 2018, 16, 147-152. [CrossRef] [PubMed]

105. Zhou, Y.; Peng, Y.; Mao, Q.Q.; Li, X.; Chen, M.W.; Su, J.; Tian, L.; Mao, N.Q.; Long, L.Z.; Quan, M.F.; et al. Casticin induces caspase-mediated apoptosis via activation of mitochondrial pathway and upregulation of dr5 in human lung cancer cells. Asian Pac. J. Trop. Med. 2013, 6, 372-378. [CrossRef]

106. Zhou, Y.; Tian, L.; Long, L.; Quan, M.; Liu, F.; Cao, J. Casticin potentiates trail-induced apoptosis of gastric cancer cells through endoplasmic reticulum stress. PLoS ONE 2013, 8, e58855. [CrossRef] [PubMed]

107. Ding, C.; Khan, M.; Zheng, B.; Yang, J.; Zhong, L.; Ma, T. Casticin induces apoptosis and mitotic arrest in pancreatic carcinoma panc-1 cells. Afr. J. Pharm. Pharmacol. 2012, 6, 412-418.

108. Meng, F.-M.; Yang, J.-B.; Yang, C.-H.; Jiang, Y.; Zhou, Y.-F.; Yu, B.; Yang, H. Vitexicarpin induces apoptosis in human prostate carcinoma pc-3 cells through g2/m phase arrest. Asian Pac. J. Cancer Prev. 2012, 13, 6369-6374. [CrossRef] [PubMed]

109. Chonghao, W. Vitexicarpin induces apoptosis-independent mitotic arrest in u87 glioblastoma cells. Afr. J. Pharm. Pharmacol. 2012, 6, 1874-1882. [CrossRef]

110. Liu, E.; Kuang, Y.; He, W.; Xing, X.; Gu, J. Casticin induces human glioma cell death through apoptosis and mitotic arrest. Cell. Physiol. Biochem. 2013, 31, 805-814. [CrossRef]

111. Song, X.-L.; Zhang, Y.-J.; Wang, X.-F.; Zhang, W.-J.; Wang, Z.; Zhang, F.; Zhang, Y.-J.; Lu, J.-H.; Mei, J.-W.; $\mathrm{Hu}$, Y.-P.; et al. Casticin induces apoptosis and $\mathrm{g} 0 / \mathrm{g} 1$ cell cycle arrest in gallbladder cancer cells. Cancer Cell Int. 2017, 17, 9. [CrossRef] [PubMed]

112. Mason, A. Plant flavone apigenin inhibits hdac and remodels chromatin to induce growth arrest and apoptosis in human prostate cancer cells: In vitro and in vivo study. Mol. Carcinogen. 2012, 51, 952-962.

113. Shukla, S.; Fu, P.; Gupta, S. Apigenin induces apoptosis by targeting inhibitor of apoptosis proteins and ku70-bax interaction in prostate cancer. Apoptosis 2014, 19, 883-894. [CrossRef]

114. Chan, L.P.; Chou, T.H.; Ding, H.Y.; Chen, P.R.; Chiang, F.Y.; Kuo, P.L.; Liang, C.H. Apigenin induces apoptosis via tumor necrosis factor receptor- and bcl-2-mediated pathway and enhances susceptibility of head and neck squamous cell carcinoma to 5-fluorouracil and cisplatin. Biochim. Biophys. Acta Gen. Subj. 2012, 1820, 1081-1091. [CrossRef] [PubMed]

115. Meng, S.; Zhu, Y.; Li, J.-F.; Wang, X.; Liang, Z.; Li, S.-Q.; Xu, X. Apigenin inhibits renal cell carcinoma cell proliferation. Oncotarget 2017, 8, 19834-19842. [CrossRef] [PubMed]

116. Shi, M.D.; Shiao, C.K.; Lee, Y.C.; Shih, Y.W. Apigenin, a dietary flavonoid, inhibits proliferation of human bladder cancer T-24 cells via blocking cell cycle progression and inducing apoptosis. Cancer Cell Int. 2015, 15, 1-12. [CrossRef]

117. Zhu, Y.; Mao, Y.Q.; Chen, H.; Lin, Y.W.; Hu, Z.H.; Wu, J.; Xu, X.; Xu, X.L.; Qin, J.; Xie, L.P. Apigenin promotes apoptosis, inhibits invasion and induces cell cycle arrest of $\mathrm{t} 24$ human bladder cancer cells. Cancer Cell Int. 2013, 13, 1-7. [CrossRef] [PubMed]

118. Wang, Q.R.; Yao, X.Q.; Wen, G.; Fan, Q.; Li, Y.J.; Fu, X.Q.; Li, C.K.; Sun, X.G. Apigenin suppresses the growth of colorectal cancer xenografts via phosphorylation and up-regulated fadd expression. Oncol. Lett. 2011, 2, 43-47. [CrossRef] [PubMed]

119. Zhang, L.; Cheng, X.; Gao, Y.; Zheng, J.; Xu, Q.; Sun, Y.; Guan, H.; Yu, H.; Sun, Z. Apigenin induces autophagic cell death in human papillary thyroid carcinoma bcpap cells. Food Funct. 2015, 6, 3464-3472. [CrossRef]

120. Liu, R.; Ji, P.; Liu, B.; Qiao, H.; Wang, X.; Zhou, L.; Deng, T.; Ba, Y. Apigenin enhances the cisplatin cytotoxic effect through p53-modulated apoptosis. Oncol. Lett. 2017, 13, 1024-1030. [CrossRef] [PubMed]

121. Masuelli, L.; Marzocchella, L.; Quaranta, A.; Palumbo, C.; Pompa, G.; Izzi, V.; Canini, A.; Modesti, A.; Galvano, F.; Bei, R. Apigenin induces apoptosis and impairs head and neck carcinomas egfr/erbb2 signaling. Front. Biosci. 2011, 16, 1060-1068. [CrossRef] 
122. Masuelli, L.; Benvenuto, M.; Mattera, R.; Di Stefano, E.; Zago, E.; Taffera, G.; Tresoldi, I.; Giganti, M.G.; Frajese, G.V.; Berardi, G.; et al. In vitro and in vivo anti-tumoral effects of the flavonoid apigenin in malignant mesothelioma. Front. Pharmacol. 2017, 8, 373. [CrossRef] [PubMed]

123. Shukla, S.; Gupta, S. Apigenin-induced cell cycle arrest is mediated by modulation of mapk, pi3k-akt, and loss of cyclin $\mathrm{d} 1$ associated retinoblastoma dephosphorylation in human prostate cancer cells. Cell Cycle 2007, 6, 1102-1114. [CrossRef] [PubMed]

124. Mehdi, S.H.; Nafees, S.; Khan, A.; Rizvi, M.A. Chrysin: A promising anticancer agent its current trends and future imedpub journals chrysin: A promising anticancer agent its current trends and future perspectives. Eur. J. Exp. Biol. 2018, 8, 16. [CrossRef]

125. Kasala, E.R.; Bodduluru, L.N.; Madana, R.M.; Athira, K.V.; Gogoi, R.; Barua, C.C. Chemopreventive and Therapeutic Potential of Chrysin in Cancer: Mechanistic Perspectives; Elsevier Ireland Ltd.: Amsterdam, The Netherlands, 2015; Volume 233, pp. 214-225.

126. Khoo, B.Y.; Chua, S.L.; Balaram, P. Apoptotic effects of chrysin in human cancer cell lines. Int. J. Mol. Sci. 2010, 11, 2188-2199. [CrossRef] [PubMed]

127. Li, X.; Wang, J.N.; Huang, J.M.; Xiong, X.K.; Chen, M.F.; Ong, C.N.; Shen, H.M.; Yang, X.F. Chrysin promotes tumor necrosis factor (tnf)-related apoptosis-inducing ligand (trail) induced apoptosis in human cancer cell lines. Toxicol. In Vitro 2011, 25, 630-635. [CrossRef] [PubMed]

128. Ryu, S.; Lim, W.; Bazer, F.W.; Song, G. Chrysin induces death of prostate cancer cells by inducing ros and er stress. J. Cell. Physiol. 2017, 232, 3786-3797. [CrossRef]

129. Xue, C.; Chen, Y.; Hu, D.N.; Iacob, C.; Lu, C.; Huang, Z. Chrysin induces cell apoptosis in human uveal melanoma cells via intrinsic apoptosis. Oncol. Lett. 2016, 4813-4820. [CrossRef]

130. Li, X.; Huang, J.M.; Wang, J.N.; Xiong, X.K.; Yang, X.F.; Zou, F. Combination of chrysin and cisplatin promotes the apoptosis of hep g2 cells by up-regulating p53. Chem.-Biol. Interact. 2015, 232, 12-20. [CrossRef]

131. Zhang, Q.; Ma, S.; Liu, B.; Liu, J.; Zhu, R.; Li, M. Chrysin induces cell apoptosis via activation of the p53/bcl-2/caspase-9 pathway in hepatocellular carcinoma cells. Exp. Ther. Med. 2016, 12, 469-474. [CrossRef]

132. Chen, Z.; Kong, S.; Song, F.; Li, L.; Jiang, H. Pharmacokinetic study of luteolin, apigenin, chrysoeriol and diosmetin after oral administration of flos chrysanthemi extract in rats. Fitoterapia 2012, 83, 1616-1622. [CrossRef] [PubMed]

133. Tuorkey, M.J. Molecular targets of luteolin in cancer. Eur. J. Cancer Prev. 2016, 25, 65-76. [CrossRef] [PubMed]

134. Hwang, J.T.; Park, O.J.; Lee, Y.K.; Sung, M.J.; Hur, H.J.; Kim, M.S.; Ha, J.H.; Kwon, D.Y. Anti-tumor effect of luteolin is accompanied by amp-activated protein kinase and nuclear factor-kb modulation in hepg2 hepatocarcinoma cells. Int. J. Mol. Med. 2011, 28, 25-31. [PubMed]

135. Lee, H.J.; Wang, C.J.; Kuo, H.C.; Chou, F.P.; Jean, L.F.; Tseng, T.H. Induction apoptosis of luteolin in human hepatoma hepg2 cells involving mitochondria translocation of bax/bak and activation of jnk. Toxicol. Appl. Pharmacol. 2005, 203, 124-131. [CrossRef]

136. Cai, X.; Ye, T.; Liu, C.; Lu, W.; Lu, M.; Zhang, J.; Wang, M.; Cao, P. Luteolin induced g2 phase cell cycle arrest and apoptosis on non-small cell lung cancer cells. Toxicol. In Vitro 2011, 25, 1385-1391. [CrossRef] [PubMed]

137. Jiang, Z.-Q.; Li, M.-H.; Qin, Y.-M.; Jiang, H.-Y.; Zhang, X.; Wu, M.-H. Luteolin inhibits tumorigenesis and induces apoptosis of non-small cell lung cancer cells via regulation of microrna-34a-5p. Int. J. Mol. Sci. 2018, 19, 447. [CrossRef] [PubMed]

138. Yang, S.F.; Yang, W.E.; Chang, H.R.; Chu, S.C.; Hsieh, Y.S. Luteolin induces apoptosis in oral squamous cancer cells. J. Dent. Res. 2008, 87, 401-406. [CrossRef]

139. Park, S.H.; Park, H.S.; Lee, J.H.; Chi, G.Y.; Kim, G.Y.; Moon, S.K.; Chang, Y.C.; Hyun, J.W.; Kim, W.J.; Choi, Y.H. Induction of endoplasmic reticulum stress-mediated apoptosis and non-canonical autophagy by luteolin in nci-h460 lung carcinoma cells. Food Chem. Toxicol. 2013, 56, 100-109. [CrossRef]

140. Wang, Q.; Wang, H.; Jia, Y.; Pan, H.; Ding, H. Luteolin induces apoptosis by ros/er stress and mitochondrial dysfunction in gliomablastoma. Cancer Chemother. Pharmacol. 2017, 79, 1031-1041. [CrossRef]

141. Johnson, J.L.; Gonzalez de Mejia, E. Interactions between dietary flavonoids apigenin or luteolin and chemotherapeutic drugs to potentiate anti-proliferative effect on human pancreatic cancer cells, in vitro. Food Chem. Toxicol. 2013, 60, 83-91. [CrossRef]

142. Yang, M.Y.; Wang, C.J.; Chen, N.F.; Ho, W.H.; Lu, F.J.; Tseng, T.H. Luteolin enhances paclitaxel-induced apoptosis in human breast cancer mda-mb-231 cells by blocking stat3. Chem.-Biol. Interact. 2014, 213, 60-68. [CrossRef] [PubMed] 
143. Cook, M.T.; Liang, Y.; Besch-Williford, C.; Hyder, S.M. Luteolin inhibits lung metastasis, cell migration, and viability of triple-negative breast cancer cells. Breast Cancer Targets Ther. 2016, 9, 9-19. [CrossRef] [PubMed]

144. Ham, S.; Kim, K.H.; Kwon, T.H.; Bak, Y.; Lee, D.H.; Song, Y.S.; Park, S.H.; Park, Y.S.; Kim, M.S.; Kang, J.W.; et al. Luteolin induces intrinsic apoptosis via inhibition of e6/e7 oncogenes and activation of extrinsic and intrinsic signaling pathways in hpv-18-associated cells. Oncol. Rep. 2014, 31, 2683-2691. [CrossRef] [PubMed]

145. Bo, W.; Zhao, X.H. Apigenin induces both intrinsic and extrinsic pathways of apoptosis in human colon carcinoma hct-116 cells. Oncol. Rep. 2017, 37, 1132-1140.

146. Chen, H.; Gao, Y.; Wu, J.; Chen, Y.; Chen, B.; Hu, J.; Zhou, J. Exploring therapeutic potentials of baicalin and its aglycone baicalein for hematological malignancies. Cancer Lett. 2014, 354, 5-11. [CrossRef]

147. Gao, Y.; Snyder, S.A.; Smith, J.N.; Chen, Y.C. Anticancer properties of baicalein: A review. Med. Chem. Res. 2016, 25, 1515-1523. [CrossRef]

148. Takahashi, H.; Chen, M.C.; Pham, H.; Angst, E.; King, J.C.; Park, J.; Brovman, E.Y.; Ishiguro, H.; Harris, D.M.; Reber, H.A.; et al. Baicalein, a component of scutellaria baicalensis, induces apoptosis by mcl-1 down-regulation in human pancreatic cancer cells. Biochim. Biophys. Acta Mol. Cell Res. 2011, 1813, 1465-1474. [CrossRef]

149. Zhou, R.-T.; He, M.; Yu, Z.; Liang, Y.; Nie, Y.; Tai, S.; Teng, C.-B. Baicalein inhibits pancreatic cancer cell proliferation and invasion via suppression of nedd 9 expression and its downstream akt and erk signaling pathways. Oncotarget 2017, 8, 56351-56363. [CrossRef]

150. Chai, Y.; Xu, J.; Yan, B. The anti-metastatic effect of baicalein on colorectal cancer. Oncol. Rep. 2017, 37, 2317-2323. [CrossRef]

151. Kim, S.J.; Kim, H.J.; Kim, H.R.; Lee, S.H.; Cho, S.D.; Choi, C.S.; Nam, J.S.; Jung, J.Y. Antitumor actions of baicalein and wogonin in ht-29 human colorectal cancer cells. Mol. Med. Rep. 2012, 6, 1443-1449. [CrossRef]

152. Mu, J.; Liu, T.; Jiang, L.; Wu, X.; Cao, Y.; Li, M.; Dong, Q.; Liu, Y.; Xu, H. The traditional chinese medicine baicalein potently inhibits gastric cancer cells. J. Cancer 2016, 7, 453-461. [CrossRef] [PubMed]

153. Liu, H.; Dong, Y.; Gao, Y.; Du, Z.; Wang, Y.; Cheng, P.; Chen, A.; Huang, H. The fascinating effects of baicalein on cancer: A review. Int. J. Mol. Sci. 2016, 17, 1681. [CrossRef] [PubMed]

154. Peng, Y.; Guo, C.; Yang, Y.; Li, F.; Zhang, Y.; Jiang, B.; Li, Q. Baicalein induces apoptosis of human cervical cancer hela cells in vitro. Mol. Med. Rep. 2015, 11, 2129-2134. [CrossRef] [PubMed]

155. Wang, Z.; Jiang, C.; Chen, W.; Zhang, G.; Luo, D.; Cao, Y.; Wu, J.; Ding, Y.; Liu, B. Baicalein induces apoptosis and autophagy via endoplasmic reticulum stress in hepatocellular carcinoma cells. Biomed. Res. Int. 2014, 2014, 732516. [CrossRef] [PubMed]

156. Cirmi, S.; Ferlazzo, N.; Lombardo, G.E.; Maugeri, A.; Calapai, G.; Gangemi, S.; Navarra, M. Chemopreventive agents and inhibitors of cancer hallmarks: May citrus offer new perspectives? Nutrients 2016, 8, 698. [CrossRef] [PubMed]

157. Periyasamy, K.; Baskaran, K.; Ilakkia, A.; Vanitha, K.; Selvaraj, S.; Sakthisekaran, D. Antitumor efficacy of tangeretin by targeting the oxidative stress mediated on 7,12-dimethylbenz(a) anthracene-induced proliferative breast cancer in sprague-dawley rats. Cancer Chemother. Pharmacol. 2015, 75, 263-272. [CrossRef] [PubMed]

158. Arivazhagan, L.; Sorimuthu Pillai, S. Tangeretin, a citrus pentamethoxyflavone, exerts cytostatic effect via p53/p21 up-regulation and suppresses metastasis in 7,12-dimethylbenz $(\alpha)$ anthracene-induced rat mammary carcinoma. J. Nutr. Biochem. 2014, 25, 1140-1153. [CrossRef] [PubMed]

159. Dong, Y.; Cao, A.; Shi, J.; Yin, P.; Wang, L.; Ji, G.; Xie, J.; Wu, D. Tangeretin, a citrus polymethoxyflavonoid, induces apoptosis of human gastric cancer ags cells through extrinsic and intrinsic signaling pathways. Oncol. Rep. 2014, 31, 1788-1794. [CrossRef] [PubMed]

160. Ma, L.L.; Wang, D.W.; Yu, X.D.; Zhou, Y.L. Tangeretin induces cell cycle arrest and apoptosis through upregulation of pten expression in glioma cells. Biomed. Pharmacother. 2016, 81, 491-496. [CrossRef]

161. Liu, X.; Chen, L.; Liu, Y.; Zhang, T. Tangeretin sensitises human lung cancer cells to trail-induced apoptosis via ros-jnk/erk-chop pathway-mediated up-regulation of death receptor 5. Trop. J. Pharm. Res. 2017, 16, 17-29. [CrossRef]

162. Kim, C.D.; Cha, J.D.; Li, S.; Cha, I.H. The mechanism of acacetin-induced apoptosis on oral squamous cell carcinoma. Arch. Oral Biol. 2015, 60, 1283-1298. [CrossRef] [PubMed] 
163. Kim, H.R.; Park, C.G.; Jung, J.Y. Acacetin (5,7-dihydroxy-4'-methoxyflavone) exhibits in vitro and in vivo anticancer activity through the suppression of nf-kb/akt signaling in prostate cancer cells. Int. J. Mol. Med. 2014, 33, 317-324. [CrossRef] [PubMed]

164. Yomogida, S. Acacetin induces apoptosis in human t cell leukemia jurkat cells via activation of a caspase cascade. Oncol. Rep. 2011, 204-209. [CrossRef] [PubMed]

165. Salimi, A.; Roudkenar, M.H.; Sadeghi, L.; Mohseni, A.; Seydi, E.; Pirahmadi, N.; Pourahmad, J. Selective anticancer activity of acacetin against chronic lymphocytic leukemia using both in vivo and in vitro methods: Key role of oxidative stress and cancerous mitochondria. Nutr. Cancer 2016, 68, 1404-1416. [CrossRef] [PubMed]

166. Shen, K.-H.; Hung, S.-H.; Yin, L.-T.; Huang, C.-S.; Chao, C.-H.; Liu, C.-L.; Shih, Y.-W. Acacetin, a flavonoid, inhibits the invasion and migration of human prostate cancer du145 cells via inactivation of the p38 mapk signaling pathway. Mol. Cell. Biochem. 2010, 333, 279-291. [CrossRef] [PubMed]

167. Shim, H.-Y.; Park, J.-H.; Paik, H.-D.; Nah, S.-Y.; Kim, D.S.H.L.; Han, Y.S. Molecules and acacetin-induced apoptosis of human breast cancer mcf-7 cells involves caspase cascade, mitochondria-mediated death signaling and sapk/jnk1/2-c-jun activation. Mol. Cells 2007, 24, 95-104. [PubMed]

168. Ni, W.; Ji, J.; Dai, Z.; Papp, A.; Johnson, A.J.; Ahn, S.; Farley, K.L.; Lin, T.S.; Dalton, J.T.; Li, X.; et al. Flavopiridol pharmacogenetics: Clinical and functional evidence for the role of slco1b1/oatp1b1 in flavopiridol disposition. PLoS ONE 2010, 5, e13792. [CrossRef]

169. Li, L.; Pongtornpipat, P.; Tiutan, T.; Kendrick, S.L.; Park, S.; Persky, D.O.; Rimsza, L.M.; Puvvada, S.D.; Schatz, J.H. Synergistic induction of apoptosis in high-risk dlbcl by bcl2 inhibition with abt-199 combined with pharmacologic loss of mcl1. Leukemia 2015, 29, 1702-1712. [CrossRef] [PubMed]

170. Mahoney, E.; Lucas, D.M.; Gupta, S.V.; Wagner, A.J.; Herman, S.E.M.; Smith, L.L.; Yeh, Y.-Y.; Andritsos, L.; Jones, J.A.; Flynn, J.M.; et al. Er stress and autophagy: New players in the mechanism of action and drug resistance of the cyclin-dependent kinase inhibitor flavopiridol. Blood 2012, 120, 1262-1273. [CrossRef] [PubMed]

171. Wiernik, P.H. Alvocidib (flavopiridol) for the treatment of chronic lymphocytic leukemia. Expert Opin. Investig. Drugs 2016, 25, 729-734. [CrossRef] [PubMed]

172. Zhang, H.P.; Li, G.Q.; Zhang, Y.; Guo, W.Z.; Zhang, J.K.; Li, J.; Lv, J.F.; Zhang, S.J. Upregulation of mcl-1 inhibits jq1-triggered anticancer activity in hepatocellular carcinoma cells. Biochem. Biophys. Res. Commun. 2018, 495, 2456-2461. [CrossRef] [PubMed]

173. Kwak, M.S.; Yu, S.J.; Yoon, J.H.; Lee, S.H.; Lee, S.M.; Lee, J.H.; Kim, Y.J.; Lee, H.S.; Kim, C.Y. Synergistic anti-tumor efficacy of doxorubicin and flavopiridol in an in vivo hepatocellular carcinoma model. J. Cancer Res. Clin. Oncol. 2015, 141, 2037-2045. [CrossRef] [PubMed]

174. Gokce, O.; Dogan Turacli, I.; Ilke Onen, H.; Erdem, O.; Erguven Kayaa, E.; Ekmekci, A. Flavopiridol induces apoptosis via mitochondrial pathway in b16f10 murine melanoma cells and a subcutaneous melanoma tumor model. Acta Dermatovenerol. Croat. 2016, 24, 2-12. [PubMed]

175. Zocchi, L.; Wu, S.C.; Wu, J.; Hayama, K.L.; Benavente, C.A. The cyclin-dependent kinase inhibitor flavopiridol (alvocidib) inhibits metastasis of human osteosarcoma cells. Oncotarget 2018, 9, 23505-23518. [CrossRef] [PubMed]

176. Huynh, D.L.; Sharma, N.; Kumar Singh, A.; Singh Sodhi, S.; Zhang, J.J.; Mongre, R.K.; Ghosh, M.; Kim, N.; Ho Park, Y.; Kee Jeong, D. Anti-tumor activity of wogonin, an extract from scutellaria baicalensis, through regulating different signaling pathways. Chin. J. Nat. Med. 2017, 15, 15-40. [CrossRef]

177. Ge, W.; Yin, Q.; Xian, H. Wogonin induced mitochondrial dysfunction and endoplasmic reticulum stress in human malignant neuroblastoma cells via ire1 $\alpha$-dependent pathway. J. Mol. Neurosci. 2015, 56, 652-662. [CrossRef] [PubMed]

178. He, F.; Wang, Q.; Zheng, X.L.; Yan, J.Q.; Yang, L.; Sun, H.; Hu, L.N.; Lin, Y.; Wang, X. Wogonin potentiates cisplatin-induced cancer cell apoptosis through accumulation of intracellular reactive oxygen species. Oncol. Rep. 2012, 28, 601-605. [CrossRef] [PubMed]

179. Ruibin, J.; Bo, J.; Danying, W.; Chihong, Z.; Jianguo, F.; Linhui, G. Therapy effects of wogonin on ovarian cancer cells. BioMed Res. Int. 2017, 2017, 9381513. [CrossRef]

180. Xu, M.; Lu, N.; Zhang, H.; Dai, Q.; Wei, L.; Li, Z.; You, Q.; Guo, Q. Wogonin induced cytotoxicity in human hepatocellular carcinoma cells by activation of unfolded protein response and inactivation of akt. Hepatol. Res. 2013, 43, 890-905. [CrossRef] 
181. Li, S.-J.; Sun, S.-J.; Gao, J.; Sun, F.-B. Wogonin induces beclin-1/pi3k and reactive oxygen species-mediated autophagy in human pancreatic cancer cells. Oncol. Lett. 2016, 12, 5059-5067. [CrossRef]

182. Androutsopoulos, V.; Arroo, R.R.J.; Hall, J.F.; Surichan, S.; Potter, G.A. Antiproliferative and cytostatic effects of the natural product eupatorin on mda-mb-468 human breast cancer cells due to cyp1-mediated metabolism. Breast Cancer Res. 2008, 10, 1-12. [CrossRef]

183. Lee, K.; Hyun Lee, D.; Jung, Y.J.; Shin, S.Y.; Lee, Y.H. The natural flavone eupatorin induces cell cycle arrest at the $\mathrm{g} 2 / \mathrm{m}$ phase and apoptosis in hela cells. Appl. Biol. Chem. 2016, 59, 193-199. [CrossRef]

184. Sarvestani, N.N.; Sepehri, H.; Farimani, M.M. Anticancer effect of eupatorin via bax/bcl-2 and mitochondrial membrane potential changes through ros mediated pathway in human colon cancer. Int. J. Pharmacogn. Phytochem. Res. 2015, 7, 1039-1046.

185. Sarvestani, N.N.; Sepehri, H.; Delphi, L.; Farimani, M.M. Eupatorin and salvigenin potentiate doxorubicin-induced apoptosis and cell cycle arrest in ht-29 and sw948 human colon cancer cells. Asian Pac. J. Cancer Prev. 2018, 19, 131-139.

186. Estévez, S.; Marrero, M.T.; Quintana, J.; Estévez, F. Eupatorin-induced cell death in human leukemia cells is dependent on caspases and activates the mitogen-activated protein kinase pathway. PLoS ONE 2014, 9, e112536. [CrossRef] [PubMed]

187. Fan, Y.; Lu, H.; Ma, H.; Feng, F.; Hu, X.; Zhang, Q.; Wang, J.; Xu, Y.; Zhao, Q. Bioactive compounds of eriocaulon sieboldianum blocking proliferation and inducing apoptosis of hepg2 cells might be involved in aurora kinase inhibition. Food Funct. 2015, 6, 3746-3759. [CrossRef] [PubMed]

188. López De Las Hazas, M.C.; Mosele, J.I.; Macià, A.; Ludwig, I.A.; Motilva, M.J. Exploring the colonic metabolism of grape and strawberry anthocyanins and their in vitro apoptotic effects in ht-29 colon cancer cells. J. Agric. Food Chem. 2017, 65, 6477-6487. [CrossRef]

189. Wang, L.S.; Stoner, G.D. Anthocyanins and their role in cancer prevention. Cancer Lett. 2008, 269, $281-290$. [CrossRef]

190. Lin, B.W.; Gong, C.C.; Song, H.F.; Cui, Y.Y. Effects of anthocyanins on the prevention and treatment of cancer. Br. J. Pharmacol. 2017, 174, 1226-1243. [CrossRef]

191. Rupasinghe, H.P.V.; Arumuggam, N.; Amararathna, M.; De Silva, A.B.K.H. The potential health benefits of haskap (Lonicera caerulea L.): Role of cyanidin-3-o-glucoside. J. Funct. Foods 2018, 44, 24-39. [CrossRef]

192. Sorrenti, V.; Vanella, L.; Acquaviva, R.; Cardile, V.; Giofrè, S.; Di Giacomo, C. Cyanidin induces apoptosis and differentiation in prostate cancer cells. Int. J. Oncol. 2015, 47, 1303-1310. [CrossRef] [PubMed]

193. Hosseini, M.M.; Karimi, A.; Behroozaghdam, M.; Javidi, M.A.; Ghiasvand, S.; Bereimipour, A.; Aryan, H.; Nassiri, F.; Jangholi, E. Cytotoxic and apoptogenic effects of cyanidin-3-glucoside on the glioblastoma cell line. World Neurosurg. 2017, 108, 94-100. [CrossRef] [PubMed]

194. Tang, J.; Oroudjev, E.; Wilson, L.; Ayoub, G. Delphinidin and cyanidin exhibit antiproliferative and apoptotic effects in mcf7 human breast cancer cells. Integr. Cancer Sci. Ther. 2015, 2, 82-86.

195. Liu, X.; Zhang, D.; Hao, Y.; Liu, Q.; Wu, Y.; Liu, X.; Luo, J.; Zhou, T.; Sun, B.; Luo, X.; et al. Cyanidin curtails renal cell carcinoma tumorigenesis. Cell. Physiol. Biochem. 2018, 46, 2517-2531. [CrossRef] [PubMed]

196. Hyun, J.W.; Chung, H.S. Cyanidin and malvidin from oryza sativa cv. Heugjinjubyeo mediate cytotoxicity against human monocytic leukemia cells by arrest of $\mathrm{g}(2) / \mathrm{m}$ phase and induction of apoptosis. J. Agric. Food Chem. 2004, 52, 2213-2217. [CrossRef] [PubMed]

197. Zhou, L.; Wang, H.; Yi, J.; Yang, B.; Li, M.; He, D.; Yang, W.; Zhang, Y.; Ni, H. Anti-tumor properties of anthocyanins from lonicera caerulea 'beilei' fruit on human hepatocellular carcinoma: In vitro and in vivo study. Biomed. Pharmacother. 2018, 104, 520-529. [CrossRef] [PubMed]

198. Karthi, N.; Kalaiyarasu, T.; Kandakumar, S.; Mariyappan, P.; Manju, V. Pelargonidin induces apoptosis and cell cycle arrest: Via a mitochondria mediated intrinsic apoptotic pathway in ht29 cells. RSC Adv. 2016, 6, 45064-45076. [CrossRef]

199. Wang, L.S.; Sun, X.D.; Cao, Y.; Wang, L.; Li, F.J.; Wang, Y.F. Antioxidant and pro-oxidant properties of acylated pelargonidin derivatives extracted from red radish (raphanus sativus var. Niger, brassicaceae). Food Chem. Toxicol. 2010, 48, 2712-2718. [CrossRef]

200. Chen, Y.; Wang, S.; Geng, B.; Yi, Z. Pelargonidin induces antitumor effects in human osteosar-Coma cells via autophagy induction, loss of mitochondrial membrane potential, $\mathrm{g} 2 / \mathrm{m}$ cell cycle arrest and downregula—tion of pi3k/akt signalling pathway. J. BUON 2018, 23, 735-740. 
201. Ko, H.; Jeong, M.-H.; Jeon, H.; Sung, G.-J.; So, Y.; Kim, I.; Son, J.; Lee, S.-W.; Yoon, H.-G.; Choi, K.-C. Delphinidin sensitizes prostate cancer cells to trail-induced apoptosis, by inducing dr5 and causing caspase-mediated hdac3 cleavage. Oncotarget 2015, 6, 9970-9984. [CrossRef]

202. Lim, W.; Song, G. Inhibitory effects of delphinidin on the proliferation of ovarian cancer cells via pi3k/akt and erk 1/2 mapk signal transduction. Oncol. Lett. 2017, 14, 810-818. [CrossRef]

203. Pal, H.C.; Sharma, S.; Strickland, L.R.; Agarwal, J.; Athar, M.; Elmets, C.A.; Afaq, F. Delphinidin reduces cell proliferation and induces apoptosis of non-small-cell lung cancer cells by targeting egfr/vegfr2 signaling pathways. PLoS ONE 2013, 8, e77270. [CrossRef] [PubMed]

204. Alhosin, M.; León-González, A.J.; Dandache, I.; Lelay, A.; Rashid, S.K.; Kevers, C.; Pincemail, J.; Fornecker, L.M.; Mauvieux, L.; Herbrecht, R.; et al. Bilberry extract (antho 50) selectively induces redox-sensitive caspase 3-related apoptosis in chronic lymphocytic leukemia cells by targeting the bcl-2/bad pathway. Sci. Rep. 2015, 5, 1-10. [CrossRef] [PubMed]

205. Bin Hafeez, B.; Asim, M.; Siddiqui, I.A.; Adhami, V.M.; Murtaza, I.; Mukhtar, H. Delphinidin, a dietary anthocyanidin in pigmented fruits and vegetables: A new weapon to blunt prostate cancer growth. Cell Cycle 2008, 7, 3320-3326. [CrossRef] [PubMed]

206. Hafeez, B.B.; Siddiqui, I.A.; Asim, M.; Malik, A.; Afaq, F.; Adhami, V.M.; Saleem, M.; Din, M.; Mukhtar, H. A dietary anthocyanidin delphinidin induces apoptosis of human prostate cancer pc3 cells in vitro and in vivo: Involvement of nuclear factor-kappab signaling. Cancer Res. 2008, 68, 8564-8572. [CrossRef]

207. Li, H.Q.; Luo, Y.; Qiao, C.H. The mechanisms of anticancer agents by genistein and synthetic derivatives of isoflavone. Mini-Rev. Med. Chem. 2012, 12, 350-362. [PubMed]

208. Spagnuolu, C.; Russo, G.L.; Orhan, 1.E.; Habtemariam, S.; Daglia, M.; Sureda, A.; Nabavi, S.F.; Devi, K.P.; Loizzo, M.R.; Tundis, R.; et al. Genistein and cancer: Current status, challenges, and future directions. Adv. Nutr. Int. Rev. J. 2015, 6, 408-419. [CrossRef]

209. Choi, E.J.; Jung, J.Y.; Kim, G.-H. Genistein inhibits the proliferation and differentiation of mcf-7 and 3t3-11 cells via the regulation of er $\alpha$ expression and induction of apoptosis. Exp. Ther. Med. 2014, 8, 454-458. [CrossRef] [PubMed]

210. Pan, H.; Zhou, W.; He, W.; Liu, X.; Ding, Q.; Ling, L.; Zha, X.; Wang, S. Genistein inhibits mda-mb-231 triple-negative breast cancer cell growth by inhibiting $\mathrm{nf}-\mathrm{kb}$ activity via the notch-1 pathway. Int. J. Mol. Med. 2012, 30, 337-343. [CrossRef] [PubMed]

211. Ullah, M.F.; Ahmad, A.; Zubair, H.; Khan, H.Y.; Wang, Z.; Sarkar, F.H.; Hadi, S.M. Soy isoflavone genistein induces cell death in breast cancer cells through mobilization of endogenous copper ions and generation of reactive oxygen species. Mol. Nutr. Food Res. 2011, 55, 553-559. [CrossRef] [PubMed]

212. Solomon, L.A.; Ali, S.; Banerjee, S.; Munkarah, A.R.; Morris, R.T.; Sarkar, F.H. Sensitization of ovarian cancer cells to cisplatin by genistein: the role of NF-kappaB. J. Ovarian Res. 2008, 1, 9. [CrossRef] [PubMed]

213. Szliszka, E.; Krol, W. Soy isoflavones augment the effect of trail-mediated apoptotic death in prostate cancer cells. Oncol. Rep. 2011, 26, 533-541. [PubMed]

214. Dong, X.; Xu, W.; Sikes, R.A.; Wu, C. Combination of low dose of genistein and daidzein has synergistic preventive effects on isogenic human prostate cancer cells when compared with individual soy isoflavone. Food Chem. 2013, 141, 1923-1933. [CrossRef] [PubMed]

215. Kumi-Diaka, J.; Merchant, K.; Haces, A.; Hormann, V.; Johnson, M. Genistein-selenium combination induces growth arrest in prostate cancer cells. J. Med. Food 2010, 13, 842-850. [CrossRef] [PubMed]

216. Qi, W.; Weber, C.R.; Wasland, K.; Savkovic, S.D. Genistein inhibits proliferation of colon cancer cells by attenuating a negative effect of epidermal growth factor on tumor suppressor foxo3 activity. BMC Cancer 2011, 11, 219. [CrossRef] [PubMed]

217. Qin, J.; Teng, J.; Zhu, Z.; Chen, J.; Huang, W.J. Genistein induces activation of the mitochondrial apoptosis pathway by inhibiting phosphorylation of akt in colorectal cancer cells. Pharm. Biol. 2016, 54, 74-79. [CrossRef] [PubMed]

218. Shafiee, G.; Saidijam, M.; Tavilani, H.; Ghasemkhani, N.; Khodadadi, I. Genistein induces apoptosis and inhibits proliferation of ht29 colon cancer cells. Int. J. Mol. Cell. Med. 2016, 5, 178-191.

219. Jin, S.; Zhang, Q.Y.; Kang, X.M.; Wang, J.X.; Zhao, W.H. Daidzein induces mcf-7 breast cancer cell apoptosis via the mitochondrial pathway. Ann. Oncol. 2010, 21, 263-268. [CrossRef]

220. Liu, X.; Suzuki, N.; Laxmi, Y.R.S.; Okamoto, Y.; Shibutani, S. Anti-breast cancer potential of daidzein in rodents. Life Sci. 2012, 91, 415-419. [CrossRef] 
221. Park, H.J.; Jeon, Y.K.; You, D.H.; Nam, M.J. Daidzein causes cytochrome c-mediated apoptosis via the bcl-2 family in human hepatic cancer cells. Food Chem. Toxicol. 2013, 60, 542-549. [CrossRef]

222. Sak, K. Cytotoxicity of dietary flavonoids on different human cancer types. Pharmacogn. Rev. 2014, 8, 122-146. [CrossRef] [PubMed]

223. Siddiqui, I.A.; Asim, M.; Hafeez, B.B.; Adhami, V.M.; Tarapore, R.S.; Mukhtar, H. Green tea polyphenol egcg blunts androgen receptor function in prostate cancer. FASEB J. 2011, 25, 1198-1207. [CrossRef] [PubMed]

224. Albrecht, D.S.; Clubbs, E.A.; Ferruzzi, M.; Bomser, J.A. Epigallocatechin-3-gallate (egcg) inhibits pc-3 prostate cancer cell proliferation via mek-independent erk1/2 activation. Chem.-Biol. Interact. 2008, 171, 89-95. [CrossRef] [PubMed]

225. Sadava, D.; Whitlock, E.; Kane, S.E. The green tea polyphenol, epigallocatechin-3-gallate inhibits telomerase and induces apoptosis in drug-resistant lung cancer cells. Biochem. Biophys. Res. Commun. 2007, 360, 233-237. [CrossRef] [PubMed]

226. Rieger-Christ, K.M.; Hanley, R.; Lodowsky, C.; Bernier, T.; Vemulapalli, P.; Roth, M.; Kim, J.; Yee, A.S.; Le, S.M.; Marie, P.J.; et al. The green tea compound, (-)-epigallocatechin-3-gallate downregulates n-cadherin and suppresses migration of bladder carcinoma cells. J. Cell. Biochem. 2007, 102, 377-388. [CrossRef] [PubMed]

227. Righeschi, C.; Eichhorn, T.; Karioti, A.; Bilia, A.R.; Efferth, T. Microarray-based mrna expression profiling of leukemia cells treated with the flavonoid, casticin. Cancer Genom. Proteomics 2012, 9, 143-151.

228. Liu, F.; Cao, X.; Liu, Z.; Guo, H.; Ren, K.; Quan, M.; Zhou, Y.; Xiang, H.; Cao, J. Casticin suppresses self-renewal and invasion of lung cancer stem-like cells from a549 cells through down-regulation of pakt. Acta Biochim. Biophys. Sin. 2014, 46, 15-21. [CrossRef]

229. Shen, J.-K.; Du, H.-P.; Yang, M.; Wang, Y.-G.; Jin, J. Casticin induces leukemic cell death through apoptosis and mitotic catastrophe. Ann.Hematol. 2009, 88, 743-752. [CrossRef]

230. Roh, J.S.; Han, J.Y.; Kim, J.H.; Hwang, J.K. Inhibitory effects of active compounds isolated from safflower (Carthamus tinctorius L.) seeds for melanogenesis. Biol. Pharm. Bull. 2004, 27, 1976-1978. [CrossRef]

231. Wirger, A.; Perabo, F.G.E.; Burgemeister, S.; Haase, L.; Schmidt, D.H.; Doehn, C.; Mueller, S.C.; Jocham, D. Flavopiridol, an inhibitor of cyclin-dependent kinases, induces growth inhibition and apoptosis in bladder cancer cells in vitro and in vivo. Anticancer Res. 2005, 25, 4341-4347.

232. Mayer, F.; Mueller, S.; Malenke, E.; Kuczyk, M.; Hartmann, J.T.; Bokemeyer, C. Induction of apoptosis by flavopiridol unrelated to cell cycle arrest in germ cell tumour derived cell lines. Investig. New Drugs 2005, 23, 205-211. [CrossRef] [PubMed]

233. Schrump, D.S.; Matthews, W.; Chen, G.A.; Mixon, A.; Altorki, N.K. Flavopiridol mediates cell cycle arrest and apoptosis in esophageal cancer cells. Clin Cancer Res. 1998, 4, 2885-2890. [PubMed]

234. Patel, V.; Senderowicz, A.M.; Pinto, D., Jr.; Igishi, T.; Raffeld, M.; Quintanilla-Martinez, L.; Ensley, J.F.; Sausville, E.A.; Gutkind, J.S. Flavopiridol, a novel cyclin-dependent kinase inhibitor, suppresses the growth of head and neck squamous cell carcinomas by inducing apoptosis. J. Clin. Investig. 1998, 102, 1674-1681. [CrossRef] [PubMed]

235. Parker, B.W.; Kaur, G.; Nieves-Neira, W.; Taimi, M.; Kohlhagen, G.; Shimizu, T.; Losiewicz, M.D.; Pommier, Y.; Sausville, E.A.; Senderowicz, A.M. Early induction of apoptosis in hematopoietic cell lines after exposure to flavopiridol. Blood 1998, 91, 458-465. [PubMed]

236. Dolečková, I.; Rárová, L.; Grúz, J.; Vondrusová, M.; Strnad, M.; Kryštof, V. Antiproliferative and antiangiogenic effects of flavone eupatorin, an active constituent of chloroform extract of orthosiphon stamineus leaves. Fitoterapia 2012, 83, 1000-1007. [CrossRef] [PubMed]

237. Yoshino, Y.; Yuan, B.; Okusumi, S.; Aoyama, R.; Murota, R.; Kikuchi, H.; Takagi, N.; Toyoda, H. Enhanced cytotoxic effects of arsenite in combination with anthocyanidin compound, delphinidin, against a human leukemia cell line, hl-60. Chem.-Biol. Interact. 2018, 294, 9-17. [CrossRef]

238. Kamenickova, A.; Anzenbacherova, E.; Pavek, P.; Soshilov, A.A.; Denison, M.S.; Anzenbacher, P.; Dvorak, Z. Pelargonidin activates the ahr and induces cyp1a1 in primary human hepatocytes and human cancer cell lines hepg2 and ls174t. Toxico. Lett. 2013, 218, 253-259. [CrossRef]

239. Sanaei, M.; Kavoosi, F.; Valiani, A.; Ghobadifar, M.A. Effect of genistein on apoptosis and proliferation of hepatocellular carcinoma hepa1-6 cell line. Int. J. Prev. Med. 2018, 9, 12. 
240. Bi, Y.L.; Min, M.; Shen, W.; Liu, Y. Genistein induced anticancer effects on pancreatic cancer cell lines involves mitochondrial apoptosis, g0/g1cell cycle arrest and regulation of stat3 signalling pathway. Phytomed. Int. J. Phytother. Phytopharmacol. 2018, 39, 10-16.

241. Gundogdu, G.; Dodurga, Y.; Cetin, M.; Secme, M.; Cicek, B. The cytotoxic and genotoxic effects of daidzein on mia paca-2 human pancreatic carcinoma cells and ht-29 human colon cancer cells. Drug chem. Toxicol. 2018. [CrossRef]

242. Hua, F.; Li, C.H.; Chen, X.G.; Liu, X.P. Daidzein exerts anticancer activity towards skov3 human ovarian cancer cells by inducing apoptosis and cell cycle arrest, and inhibiting the raf/mek/erk cascade. Int. J. Mol. Med. 2018, 41, 3485-3492. [CrossRef] [PubMed]

243. Han, B.-J.; Li, W.; Jiang, G.-B.; Lai, S.-H.; Zhang, C.; Zeng, C.-C.; Liu, Y.-J. Effects of daidzein in regards to cytotoxicity in vitro, apoptosis, reactive oxygen species level, cell cycle arrest and the expression of caspase and bcl-2 family proteins. Oncol. Rep. 2015, 34, 1115-1120. [CrossRef] [PubMed]

244. Hollman, P.C.H. Absorption, bioavailability, and metabolism of flavonoids. Pharm. Biol. 2004, 42, 74-83. [CrossRef]

245. Manach, C.; Scalbert, A.; Morand, C.; Remesy, C.; Jimenez, L. Polyphenols: Food sources and bioavailability. Am. J. Clin. Nutr. 2004, 79, 727-747. [CrossRef]

246. Viskupičová, J.; Ondrejovič, M.; Šturdík, E. Bioavailability and metabolism of flavonoids. J. Food Nutr. Res. 2008, 47, 151-162.

247. Cassidy, A.; Minihane, A.M. The role of metabolism (and the microbiome) in defining the clinical efficacy of dietary flavonoids. Am. J. Clin. Nutr. 2017, 105, 10-22. [CrossRef]

248. Scalbert, A.; Williamson, G. Dietary intake and bioavailability of polyphenols. J. Nutr. 2000, 130, 2073 S-2085S. [CrossRef]

249. Hu, M.; Wu, B.; Liu, Z. Bioavailability of polyphenols and flavonoids in the era of precision medicine. Mol. Pharm. 2017, 14, 2861-2863. [CrossRef]

250. Thilakarathna, S.H.; Rupasinghe, H.P. Flavonoid bioavailability and attempts for bioavailability enhancement. Nutrients 2013, 5, 3367-3387. [CrossRef]

251. Barnes, S. Soy isoflavones-phytoestrogens and what else? J. Nutr. 2004, 134, 1225S-1228S. [CrossRef]

252. Messina, M.J.; Loprinzi, C.L. Soy for breast cancer survivors: A critical review of the literature. J. Nutr. 2001, 131, 3095S-3108S. [CrossRef] [PubMed]

253. Wang, S.; Zhang, J.; Chen, M.; Wang, Y. Delivering flavonoids into solid tumors using nanotechnologies. Expert Opin. Drug Deliv. 2013, 10, 1411-1428. [CrossRef] [PubMed]

254. Goniotaki, M.; Hatziantoniou, S.; Dimas, K.; Wagner, M.; Demetzos, C. Encapsulation of naturally occurring flavonoids into liposomes: Physicochemical properties and biological activity against human cancer cell lines. J. Pharm. Pharmacol. 2004, 56, 1217-1224. [CrossRef] [PubMed]

255. Guo, D.; Wu, C.; Li, J.; Guo, A.; Li, Q.; Jiang, H.; Chen, B.; Wang, X. Synergistic effect of functionalized nickel nanoparticles and quercetin on inhibition of the smmc-7721 cells proliferation. Nanoscale Res. Lett. 2009, 4, 1395-1402. [CrossRef] [PubMed]

256. Wong, M.Y.; Chiu, G.N. Liposome formulation of co-encapsulated vincristine and quercetin enhanced antitumor activity in a trastuzumab-insensitive breast tumor xenograft model. Nanomedicine 2011, 7, 834-840. [CrossRef] [PubMed]

257. Han, Q.; Yang, R.; Li, J.; Liang, W.; Zhang, Y.; Dong, M.; Besenbacher, F.; Wang, C. Enhancement of biological activities of nanostructured hydrophobic drug species. Nanoscale 2012, 4, 2078-2082. [CrossRef] [PubMed]

258. Yuan, Z.P.; Chen, L.J.; Wei, Y.Q.; Fan, L.Y.; Tang, M.H.; Yang, G.L. Nanoliposomal quercetin inhibits formation of malignant ascites of hepatocellular carcinoma. Ai Zheng 2006, 25, 941-945. [PubMed]

259. Yuan, Z.P.; Chen, L.J.; Fan, L.Y.; Tang, M.H.; Yang, G.L.; Yang, H.S.; Du, X.B.; Wang, G.Q.; Yao, W.X.; Zhao, Q.M.; et al. Liposomal quercetin efficiently suppresses growth of solid tumors in murine models. Clin. Cancer Res. 2006, 12, 3193-3199. [CrossRef] [PubMed]

260. Ferrer, P.; Asensi, M.; Segarra, R.; Ortega, A.; Benlloch, M.; Obrador, E.; Varea, M.T.; Asensio, G.; Jorda, L.; Estrela, J.M. Association between pterostilbene and quercetin inhibits metastatic activity of b16 melanoma. Neoplasia 2005, 7, 37-47. [CrossRef]

261. Harper, C.E.; Cook, L.M.; Patel, B.B.; Wang, J.; Eltoum, I.A.; Arabshahi, A.; Shirai, T.; Lamartiniere, C.A. Genistein and resveratrol, alone and in combination, suppress prostate cancer in sv-40 tag rats. Prostate 2009, 69, 1668-1682. [CrossRef] 
262. Sakamoto, K. Synergistic effects of thearubigin and genistein on human prostate tumor cell (pc-3) growth via cell cycle arrest. Cancer Lett. 2000, 151, 103-109. [CrossRef]

263. Wang, P.; Heber, D.; Henning, S.M. Quercetin increased bioavailability and decreased methylation of green tea polyphenols in vitro and in vivo. Food Funct. 2012, 3, 635-642. [CrossRef] [PubMed]

264. Wang, P.; Vadgama, J.V.; Said, J.W.; Magyar, C.E.; Doan, N.; Heber, D.; Henning, S.M. Enhanced inhibition of prostate cancer xenograft tumor growth by combining quercetin and green tea. J. Nutr. Biochem. 2014, 25, 73-80. [CrossRef] [PubMed]

265. Amin, A.R.; Wang, D.; Zhang, H.; Peng, S.; Shin, H.J.; Brandes, J.C.; Tighiouart, M.; Khuri, F.R.; Chen, Z.G.; Shin, D.M. Enhanced anti-tumor activity by the combination of the natural compounds (-)-epigallocatechin-3-gallate and luteolin: Potential role of p53. J. Biol. Chem. 2010, 285, 34557-34565. [CrossRef] [PubMed]

266. Somers-Edgar, T.J.; Scandlyn, M.J.; Stuart, E.C.; Le Nedelec, M.J.; Valentine, S.P.; Rosengren, R.J. The combination of epigallocatechin gallate and curcumin suppresses er alpha-breast cancer cell growth in vitro and in vivo. Int. J. Cancer 2008, 122, 1966-1971. [CrossRef] [PubMed]

267. Mertens-Talcott, S.U.; Bomser, J.A.; Romero, C.; Talcott, S.T.; Percival, S.S. Ellagic acid potentiates the effect of quercetin on p21waf1/cip1, p53, and map-kinases without affecting intracellular generation of reactive oxygen species in vitro. J. Nutr. 2005, 135, 609-614. [CrossRef]

268. Mertens-Talcott, S.U.; Percival, S.S. Ellagic acid and quercetin interact synergistically with resveratrol in the induction of apoptosis and cause transient cell cycle arrest in human leukemia cells. Cancer Lett. 2005, 218, 141-151. [CrossRef]

269. Mertens-Talcott, S.U.; Talcott, S.T.; Percival, S.S. Low concentrations of quercetin and ellagic acid synergistically influence proliferation, cytotoxicity and apoptosis in molt-4 human leukemia cells. J. Nutr. 2003, 133, 2669-2674. [CrossRef]

270. Suganuma, M.; Okabe, S.; Kai, Y.; Sueoka, N.; Sueoka, E.; Fujiki, H. Synergistic effects of (-)-epigallocatechin gallate with (-)-epicatechin, sulindac, or tamoxifen on cancer-preventive activity in the human lung cancer cell line pc-9. Cancer Res. 1999, 59, 44-47.

271. Suganuma, M.; Kurusu, M.; Suzuki, K.; Tasaki, E.; Fujiki, H. Green tea polyphenol stimulates cancer preventive effects of celecoxib in human lung cancer cells by upregulation of gadd153 gene. Int. J. Cancer 2006, 119, 33-40. [CrossRef]

272. Adhami, V.M.; Malik, A.; Zaman, N.; Sarfaraz, S.; Siddiqui, I.A.; Syed, D.N.; Afaq, F.; Pasha, F.S.; Saleem, M.; Mukhtar, H. Combined inhibitory effects of green tea polyphenols and selective cyclooxygenase-2 inhibitors on the growth of human prostate cancer cells both in vitro and in vivo. Clin. Cancer Res. 2007, 13, 1611-1619. [CrossRef] [PubMed]

273. Stearns, M.E.; Wang, M. Synergistic effects of the green tea extract epigallocatechin-3-gallate and taxane in eradication of malignant human prostate tumors. Transl. Oncol. 2011, 4, 147-156. [CrossRef] [PubMed]

274. Stearns, M.E.; Amatangelo, M.D.; Varma, D.; Sell, C.; Goodyear, S.M. Combination therapy with epigallocatechin-3-gallate and doxorubicin in human prostate tumor modeling studies: Inhibition of metastatic tumor growth in severe combined immunodeficiency mice. Am. J. Pathol. 2010, 177, 3169-3179. [CrossRef] [PubMed]

275. Liang, G.; Tang, A.; Lin, X.; Li, L.; Zhang, S.; Huang, Z.; Tang, H.; Li, Q.Q. Green tea catechins augment the antitumor activity of doxorubicin in an in vivo mouse model for chemoresistant liver cancer. Int. J. Oncol. 2010, 37, 111-123. [PubMed]

276. Luo, T.; Wang, J.; Yin, Y.; Hua, H.; Jing, J.; Sun, X.; Li, M.; Zhang, Y.; Jiang, Y. (-)-epigallocatechin gallate sensitizes breast cancer cells to paclitaxel in a murine model of breast carcinoma. Breast Cancer Res. 2010, 12, R8. [CrossRef] [PubMed]

277. Chan, M.M.; Soprano, K.J.; Weinstein, K.; Fong, D. Epigallocatechin-3-gallate delivers hydrogen peroxide to induce death of ovarian cancer cells and enhances their cisplatin susceptibility. J. Cell Physiol. 2006, 207, 389-396. [CrossRef] [PubMed]

278. Tang, S.N.; Fu, J.; Shankar, S.; Srivastava, R.K. Egcg enhances the therapeutic potential of gemcitabine and cp690550 by inhibiting stat3 signaling pathway in human pancreatic cancer. PLoS ONE 2012, 7, e31067. [CrossRef] [PubMed] 
279. Staedler, D.; Idrizi, E.; Kenzaoui, B.H.; Juillerat-Jeanneret, L. Drug combinations with quercetin: Doxorubicin plus quercetin in human breast cancer cells. Cancer Chemother. Pharmacol. 2011, 68, 1161-1172. [CrossRef] [PubMed]

280. Sharma, H.; Sen, S.; Singh, N. Molecular pathways in the chemosensitization of cisplatin by quercetin in human head and neck cancer. Cancer Biol. Ther. 2005, 4, 949-955. [CrossRef]

281. Banerjee, S.; Zhang, Y.; Ali, S.; Bhuiyan, M.; Wang, Z.; Chiao, P.J.; Philip, P.A.; Abbruzzese, J.; Sarkar, F.H. Molecular evidence for increased antitumor activity of gemcitabine by genistein in vitro and in vivo using an orthotopic model of pancreatic cancer. Cancer Res. 2005, 65, 9064-9072. [CrossRef]

282. Mohammad, R.M.; Banerjee, S.; Li, Y.; Aboukameel, A.; Kucuk, O.; Sarkar, F.H. Cisplatin-induced antitumor activity is potentiated by the soy isoflavone genistein in bxpc-3 pancreatic tumor xenografts. Cancer 2006, 106, 1260-1268. [CrossRef] [PubMed]

283. Banerjee, S.; Zhang, Y.; Wang, Z.; Che, M.; Chiao, P.J.; Abbruzzese, J.L.; Sarkar, F.H. In vitro and in vivo molecular evidence of genistein action in augmenting the efficacy of cisplatin in pancreatic cancer. Int. J. Cancer 2007, 120, 906-917. [CrossRef] [PubMed]

284. Raffoul, J.J.; Sarkar, F.H.; Hillman, G.G. Radiosensitization of prostate cancer by soy isoflavones. Curr. Cancer Drug Targets 2007, 7, 759-765. [CrossRef] [PubMed]

285. Raffoul, J.J.; Banerjee, S.; Singh-Gupta, V.; Knoll, Z.E.; Fite, A.; Zhang, H.; Abrams, J.; Sarkar, F.H.; Hillman, G.G. Down-regulation of apurinic/apyrimidinic endonuclease 1/redox factor-1 expression by soy isoflavones enhances prostate cancer radiotherapy in vitro and in vivo. Cancer Res. 2007, 67, 2141-2149. [CrossRef] [PubMed]

286. Raffoul, J.J.; Banerjee, S.; Che, M.; Knoll, Z.E.; Doerge, D.R.; Abrams, J.; Kucuk, O.; Sarkar, F.H.; Hillman, G.G. Soy isoflavones enhance radiotherapy in a metastatic prostate cancer model. Int. J. Cancer 2007, 120, 2491-2498. [CrossRef] [PubMed]

287. Gupta, S.C.; Patchva, S.; Aggarwal, B.B. Therapeutic roles of curcumin: Lessons learned from clinical trials. AAPS J. 2013, 15, 195-218. [CrossRef] [PubMed]

288. Kanwar, J.; Taskeen, M.; Mohammad, I.; Huo, C.; Chan, T.H.; Dou, Q.P. Recent advances on tea polyphenols. Front. Biosci. 2012, 4, 111-131. [CrossRef]

289. Saldanha, S.N.; Tollefsbol, T.O. The role of nutraceuticals in chemoprevention and chemotherapy and their clinical outcomes. J. Oncol. 2012, 2012, 192464. [CrossRef]

290. Paller, C.J.; Rudek, M.A.; Zhou, X.C.; Wagner, W.D.; Hudson, T.S.; Anders, N.; Hammers, H.J.; Dowling, D.; King, S.; Antonarakis, E.S.; et al. A phase i study of muscadine grape skin extract in men with biochemically recurrent prostate cancer: Safety, tolerability, and dose determination. Prostate 2015, 75, 1518-1525. [CrossRef]

291. Zhang, G.; Wang, Y.; Zhang, Y.; Wan, X.; Li, J.; Liu, K.; Wang, F.; Liu, K.; Liu, Q.; Yang, C.; et al. Anti-cancer activities of tea epigallocatechin-3-gallate in breast cancer patients under radiotherapy. Curr. Mol. Med. 2012, 12, 163-176. [CrossRef]

(C) 2018 by the authors. Licensee MDPI, Basel, Switzerland. This article is an open access article distributed under the terms and conditions of the Creative Commons Attribution (CC BY) license (http:/ / creativecommons.org/licenses/by/4.0/). 